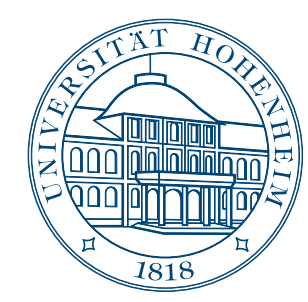

HOHENHEIM DISCUSSION PAPERS

IN BUSINESS, ECONOMICS AND SOCIAL SCIENCES

Research Area INEPA

DISCUSSION PAPER 23-2017

\title{
STRUCTURAL TRANSFORMATION AND ITS RELEVANCE FOR ECONOMIC GROWTH IN SUB-SAHARAN AFRICA
}

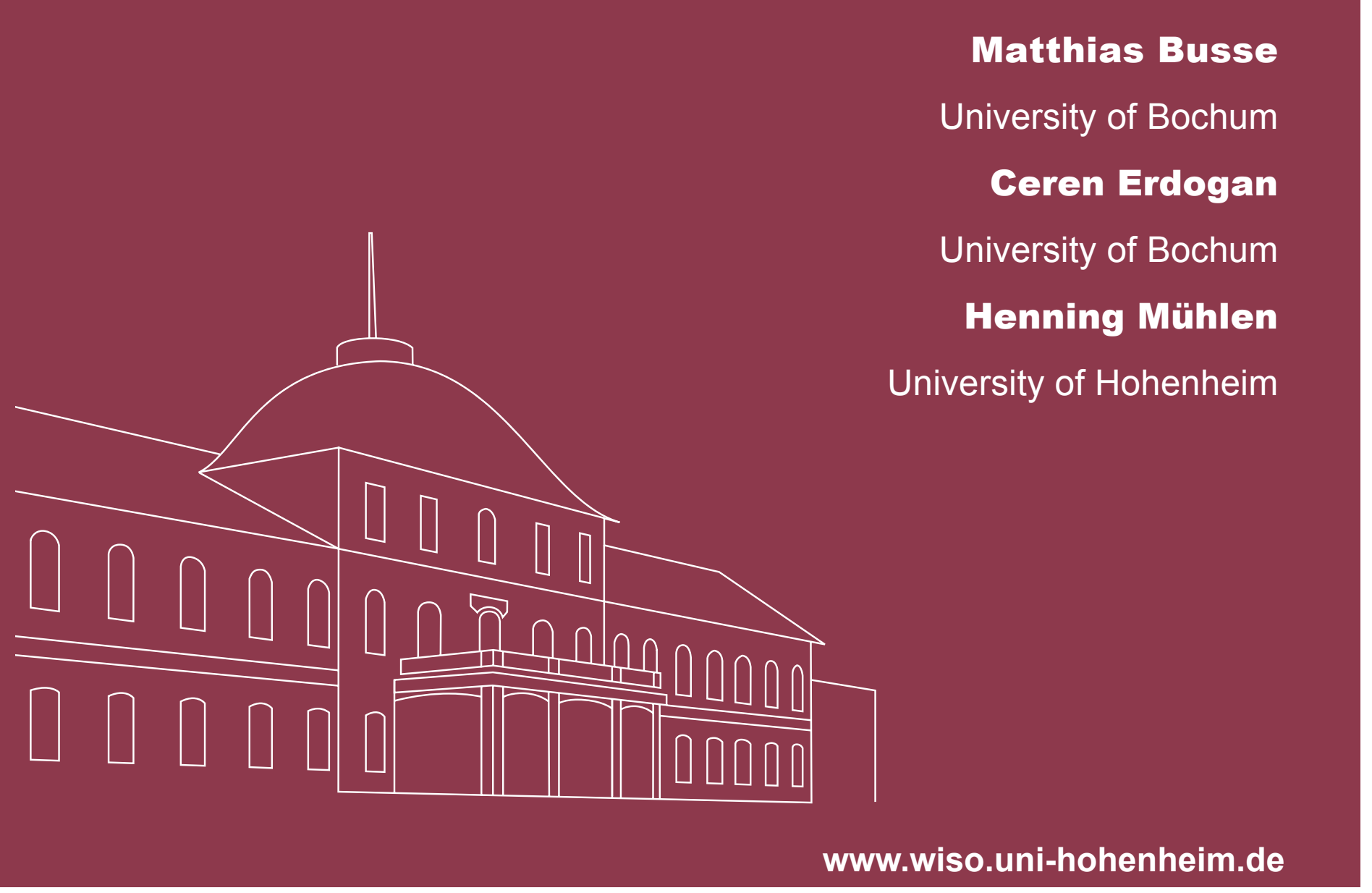




\title{
Discussion Paper 23-2017
}

\section{Structural Transformation and Its Relevance for Economic Growth in Sub-Saharan Africa}

\author{
Matthias Busse, Ceren Erdogan, Henning Mühlen \\ Research Area "INEPA - Inequality and Economic Policy Analysis"
}

Download this Discussion Paper from our homepage:

https://wiso.uni-hohenheim.de/papers

ISSN 2364-2084

Die Hohenheim Discussion Papers in Business, Economics and Social Sciences dienen der schnellen Verbreitung von Forschungsarbeiten der Fakultät Wirtschafts- und Sozialwissenschaften. Die Beiträge liegen in alleiniger Verantwortung der Autoren und stellen nicht notwendigerweise die Meinung der Fakultät Wirtschafts- und Sozialwissenschaften dar.

Hohenheim Discussion Papers in Business, Economics and Social Sciences are intended to make results of the Faculty of Business, Economics and Social Sciences research available to the public in order to encourage scientific discussion and suggestions for revisions. The authors are solely responsible for the contents which do not necessarily represent the opinion of the Faculty of Business, Economics and Social Sciences. 


\title{
Structural Transformation AND its Relevance FOR ECONOMiC Growth IN Sub-SAHARAN AFrica*
}

\author{
Matthias Busse \\ University of Bochum
}

\author{
Ceren Erdogan \\ University of Bochum
}

\author{
Henning Mühlen ${ }^{\dagger}$ \\ University of Hohenheim
}

August 30, 2017

\begin{abstract}
In this paper, we analyse the role of structural transformation in view of the remarkable growth performance of sub-Saharan African countries since the mid1990s. Our analysis covers 41 African countries over the period 1980 to 2014 and accounts for structural transformation by employing the analytical frameworks of (1) growth decomposition and (2) growth regression. Even though the low-productive agricultural sector continues to employ most of the African workforce, our results reveal that structural transformation has taken place and that it has contributed significantly to African growth in the past decades.
\end{abstract}

JEL-Classification: O11, O13, O47

Keywords: Sub-Saharan Africa, structural transformation, economic growth, growth regressions, dualistic approach

\footnotetext{
*This work is a completely revised version of the paper titled "Temporary Acceleration or Permanent Growth Take-Off? An Analysis of the Drivers of Economic Growth in sub-Saharan Africa" which is available here: http://dx.doi.org/10.2139/ssrn.2548528. We thank participants of the PEGNet conference 2015 in Berlin, the THE Christmas Workshop 2015 in Stuttgart, the Research Seminar at the Paris School of Business, and the Economics \& Politics Seminar at the University of Heidelberg for useful comments.

${ }^{\dagger}$ Corresponding author: Henning Mühlen, University of Hohenheim, Institute of Economics (520E), Schloss: Museumsflügel, 70593 Stuttgart, Germany; LHenning.Muehlen@uni-hohenheim.de
} 


\section{Introduction}

Since the time of independence, sub-Saharan African countries have seen a rather fluctuating performance in terms of economic growth 11 From the 1960s until the mid-1970s Africa experienced moderate growth achieving average annual gross domestic product (GDP) per capita growth of around two percent (Figure 1). While African growth rates were still below those of East Asian tiger economies, they were close to the world average and to those achieved by many other developing regions. But in the late 1970s and early 1980s, economic growth deteriorated rapidly. For some 20 years until the mid-1990s, average African per capita growth was even negative. Since then, Africa has seen a considerable improvement in its growth performance with positive rates of around two percent which was clearly above the world average in the early 2000s.

Figure 1: Growth Rates in Africa, 1961-2014 (5-Year Averages)

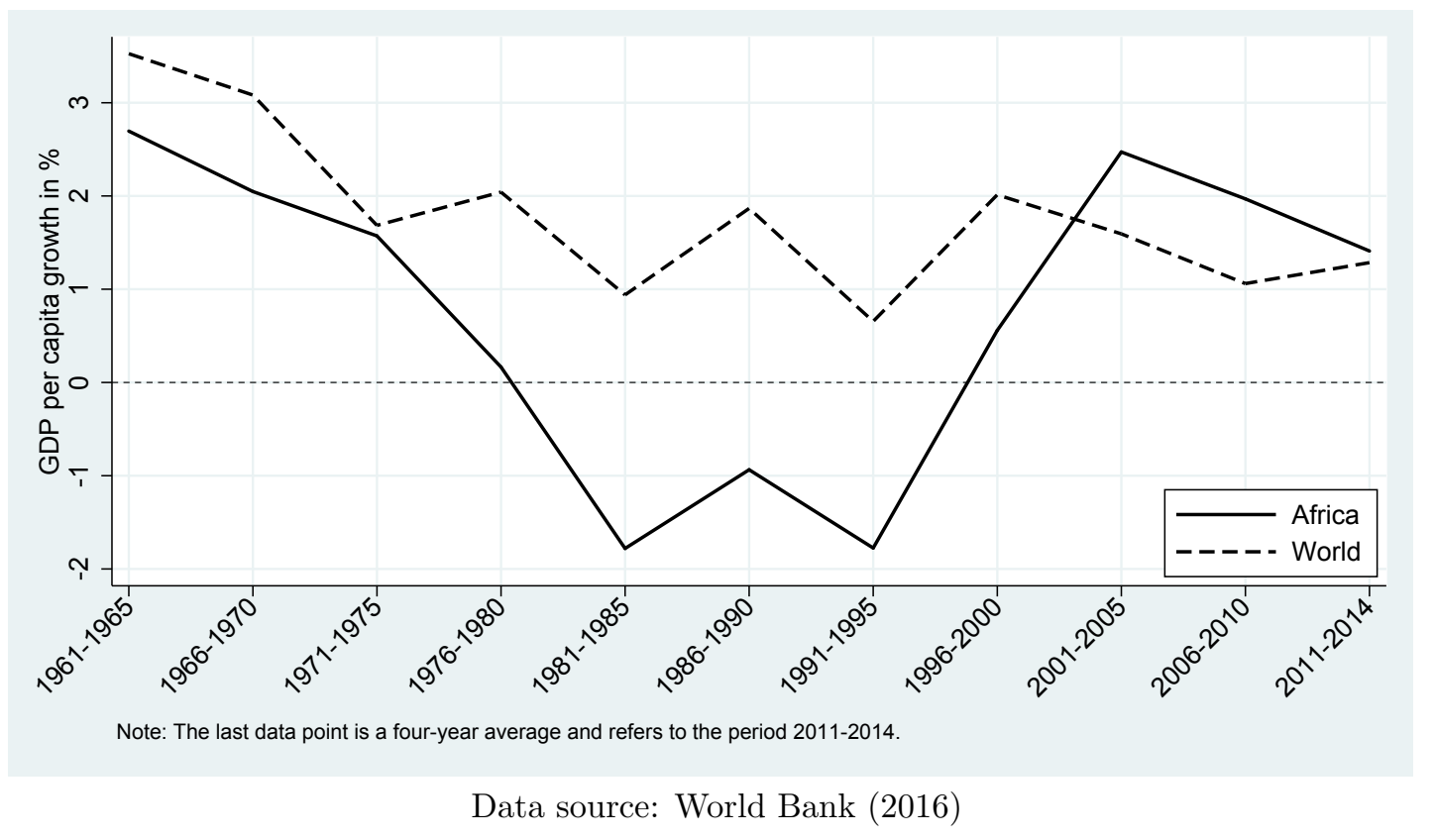

Following the region's impressive growth take-off, the perception of Africa in the media has changed remarkably. In the 1980s and 1990s, Africa was associated with high poverty levels, autocracy, diseases, wars, and corruption. In recent years, it has been viewed as a booming continent with decreasing poverty, an emerging middle class, democratisa-

\footnotetext{
${ }^{1}$ Except otherwise noted, Africa refers to sub-Saharan Africa hereafter.
} 
tion, urbanisation, a construction boom, a strongly expanding services sector, and everincreasing exports of raw materials due to a strong increase in commodity prices.$^{2}$

In addition, enhanced political stability, economic liberalisation, education and infrastructure, and less conflicts and macroeconomic distortions were also relevant for the improved economic performance of many African countries (OECD et al., 2013). With these improved "fundamental" capabilities African economies were able to lower distortions, boost (domestic and foreign) investment and significantly increase their growth rates. These developments are in line with the standard macroeconomic growth approach based on the Solow growth model. The approach emphasises that all factors that stimulate capital accumulation or foster improvements in technology, such as education, better institutions and openness to trade and foreign investment, are 'fundamental' determinants of economic growth.

While the macroeconomic approach dominated much of empirical growth research in the past two decades, recently the role of structural transformation has re-emerged (Herrendorf et al., 2014; Rodrik, 2014). According to the growth approach in development economics which is based on the dual economy model, economic growth (also) depends on the rate of structural transformation, defined as the shift in labour (and other resources) from traditional low-productivity to modern high-productivity sectors Kuznets, 1966, Lewis, 1954). In fact, since the growth take-off most African countries have also experienced some degree of structural transformation. However, there is significant variation in the speed and type of structural transformation among African countries. While European and Asian countries typically experienced structural transformation through a move from agriculture to manufacturing, many African countries have deindustrialised (Rodrik, 2016), and may rather transform through either a shift to services or productivity increases in their agricultural sectors (IMF, 2012). So far, there is little empirical evidence that structural transformation played a significant role for the recent growth performance in Africa (de Vries et al. 2015). Thus, the main objective of our paper is to

\footnotetext{
${ }^{2}$ See, for example, the shift in the coverage of Africa in The Economist over the last 15 years. In the issue on May 9, 2000, Africa was labelled "The Hopeless Continent", but in the issue on March 2, 2013, the magazine titled "Emerging Africa: A Hopeful Continent".
} 
investigate the drivers of African economic growth paying special attention to the role of structural transformation.

Prior research on structural transformation and growth in Africa is restricted to a small number of countries mainly due to limited data availability at the sectoral level (McMillan et al., 2014, McMillan and Harttgen, 2014, de Vries et al., 2015). These studies share a common empirical method, that is, they decompose aggregate growth into two components, the level of fundamental capabilities and structural transformation. However, despite the broad sectoral coverage (ten sectors), they only cover a limited number of African countries, calling into question the representativeness of their results for the whole (sub-)continent $3^{3}$ Nonetheless, these studies provide a solid foundation for our analysis. For instance, we also use the decomposition method as one of two analytical frameworks in our empirical analysis.

Moreover, we use a second analytical framework employing an augmented Solow growth model, and conduct cross-country growth regressions. Our analysis covers 41 African countries over the period 1980 to 2014. The period under consideration allows us to capture both the decline in growth rates in the early 1980s as well as the strong rebound after the mid-1990s. In addition to the standard variables explaining growth, such as capital accumulation, population growth, and fundamental capabilities, we also incorporate variables accounting for structural transformation. This is an important extension since most empirical growth research proceeds as if structural transformation can be ignored (see also the critique by Temple and Wößmann (2006)). In terms of the econometric methodology, we use a standard fixed-effects panel model. Moreover, we employ an appropriate instrumental variable approach (system GMM) to account for endogeneity issues. Hence, our analysis contributes to the existing literature to the extent that we use macro-level data with a large country-time coverage and we employ two different empirical methods, proving the robustness of our results.

The structure of the paper is as follows. After presenting a descriptive overview of sectoral productivity patterns and the role of structural transformation in Africa in Section

\footnotetext{
${ }^{3}$ For example, the paper by McMillan et al. (2014) covers only nine African countries.
} 
2. we explain the two empirical frameworks for productivity growth in Section 3. The results based on both frameworks are displayed and explained in Section 4. Finally, we discuss the results and draw conclusions and policy implications in Section 5.

\section{Facts on Sectoral Productivity in Africa}

Within this section, we present some notable facts on sectoral productivity growth patterns in Africa that reveal the relevance of structural transformation. According to Herrendorf et al. (2014, p.855), structural transformation refers to "the reallocation of economic activity across the broad sectors agriculture, manufacturing, and services". We seize on this broad definition and continue with a differentiation between agriculture on the one hand and non-agricultural sectors as an aggregate of services and manufacturing on the other hand. As we will show in the following, such a two-sector approach is appropriate in the African context and offers the main advantage of extending the country sample. Standard (production) indicators of structural transformation are sectoral employment shares and value-added data 4

Figure 2 refers to agricultural employment relative to total employment in Africa. Throughout the period 1980 to 2014 the average agricultural employment share is above 50 percent, clearly demonstrating the dominance of the agricultural sector. Starting in 1980 with 73 percent the share declines constantly to 56 percent, implying that at the same time the share of non-agricultural employment increases inversely. This is of particular interest for structural transformation as it indicates that labour moves steadily from agriculture to other sectors $5^{5}$

Moreover, Figure 2 reveals that there is considerable heterogeneity among countries as illustrated by the dashed lines of the lower and upper quartile, respectively. Although agriculture is a very important economic sector in countries belonging to the lower quartile group, their agricultural employment share steadily declines from 65 percent in 1980 to 50 percent in the late 1990 s, and finally to 39 percent in 2014. Hence, a significant part of

\footnotetext{
${ }^{4}$ See Herrendorf et al. (2014) for a detailed discussion of key measures of structural transformation.

${ }^{5}$ Note that the amount of total employment is continuously increasing throughout the time period.
} 
economic activity in terms of labour is reallocated to non-agricultural sectors over time. A country that continuously belongs to the lower quartile group, for example, is South Africa.

On the other hand, in the economies belonging to the upper quartile we can observe much lower rates of decline in the agricultural employment share, highlighting the fact that agriculture remains the dominant sector throughout the period under consideration. Burkina Faso appears to be a prominent example of this country group. Overall, we can summarize our first observations of the data in two facts:

- Fact 1: In terms of employment agriculture plays a major role in Africa although there is considerable heterogeneity among countries.

- Fact 2: The agricultural employment share is constantly decreasing suggesting that there is labour reallocation towards non-agricultural sectors.

Figure 2: Agricultural Employment Share (in \% of Total Employment), 1980-2014

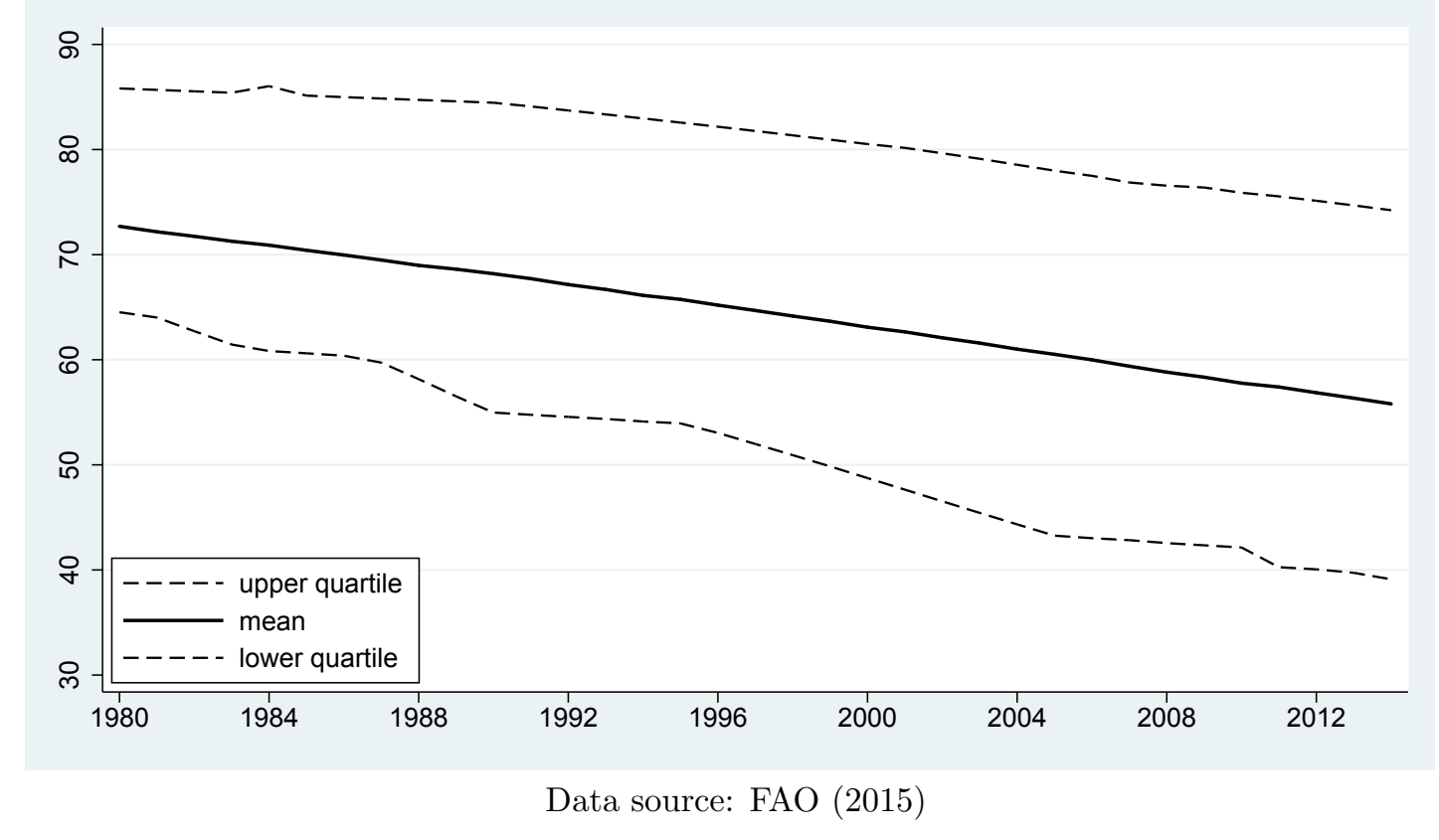

Next, we turn to data on value added presented in Figure 3(a). The graph is based on the indicator sectoral value-added in percent of GDP and illustrates the African averages over time. It is evident that each sector's share of value-added in GDP remains relatively constant over time with the services sector being most dominant. Agriculture starts 
with a share of roughly 30 percent in 1980 which decreases to about 20 percent in 2014 . Comparing agriculture with the aggregate of non-agricultural sectors, it turns out that the former - while employing the major part of the labour force (as shown above) contributes a relatively small fraction to GDP.

Hence, it is not surprising that labour productivity in non-agriculture relative to agriculture is high. This is shown in Figure 3(b) where sectoral labour productivity is defined as value-added in US dollars per employee. The figure documents the ratio of labour productivity in non-agriculture relative to labour productivity in agriculture over time. In 1980 productivity in non-agriculture is nearly ten times higher than in agriculture. This ratio decreases just marginally over time reaching roughly 600 percent in recent years. We summarize these additional observations in two further facts:

- Fact 3: In terms of value added services is the dominant sector while agriculture contributes only 20 to 30 percent.

- Fact 4: Labour productivity in agriculture is by far lower than in nonagricultural sectors.

Such productivity gaps between sectors (Fact 4) are also documented in related studies (e.g. McMillan et al., 2014) and even apply to developing countries outside of Africa. Taking into account all four facts, the overall insight of this section is that on average the movement of employment away from (low-productivity) agriculture to (high-productivity) non-agriculture should have a positive effect on productivity growth. In other words, these facts reflect growth-inducing structural transformation. Consequently, we must consider frameworks for the subsequent empirical analysis that account for sectoral changes, that is, structural transformation. 
Figure 3: Value-Added and Productivity in Africa, 1980-2014

(a) Sectoral value-added (in \% of GDP)

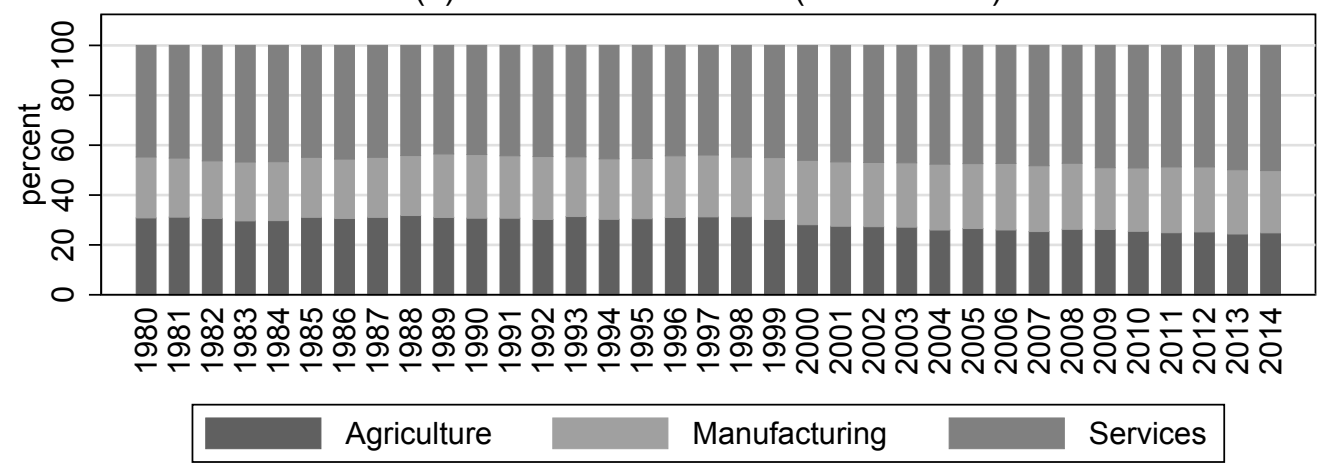

(b) Labour productivity ratio: non-agriculture relative to agriculture

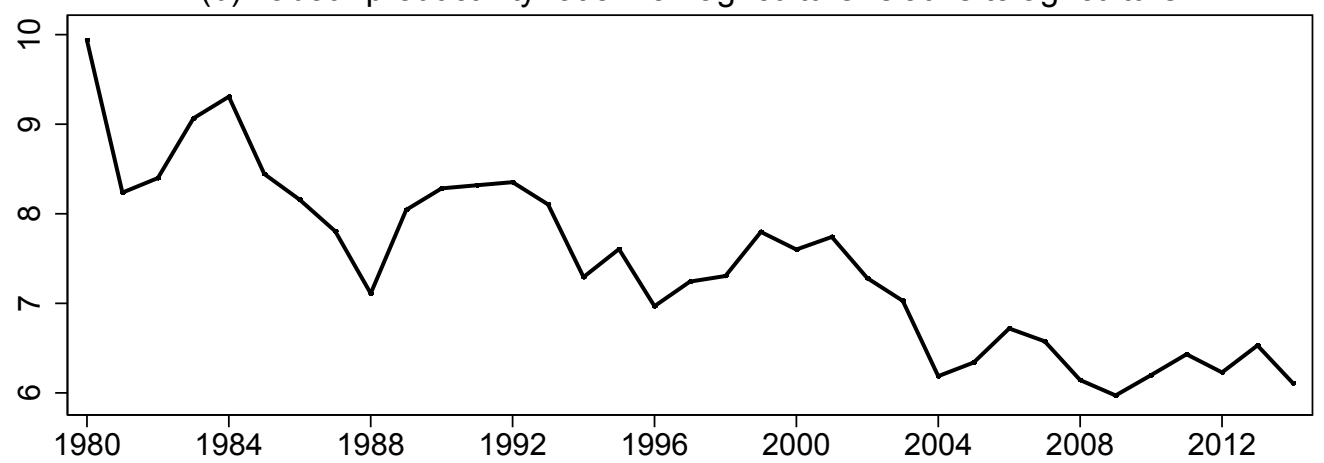

Data sources: World Bank (2016) and FAO 2015)

\section{Methodology: Frameworks Considering Structural Transformation}

Addressing our main research question concerning the role of structural transformation for economic growth in Africa, we employ two distinct analytical frameworks. The first one is a decomposition approach applied by McMillan et al. (2014) which aims to calculate the contribution of structural transformation to overall productivity change. The second one is a regression model related to the work of Temple and Wößmann (2006). Here the goal is to analyse the importance of cross-country differences in structural transformation as an explanation for variations in productivity growth. Hence, these two approaches investigate the role of structural transformation from different angles. It is worth mentioning that we apply both frameworks independent from each other. That is, we conduct two separate analyses in order to highlight the relevance of structural transformation for economic 
growth in Africa.

\subsection{The Decomposition of Productivity Change}

Based upon the arguments explained in Section 1, an increase in total GDP per worker, that is, the productivity of labour, can be decomposed into: Productivity enhancements due to the accumulation of human and physical capital (capabilities) and the move of workers from a sector with a low productivity to a sector with a high productivity (structural transformation). For changes in labour productivity in the entire economy, we have:

$$
\Delta Y_{t}=\underbrace{\sum_{i=n} \Theta_{i t-1} \Delta y_{i t}}_{\text {within component }}+\underbrace{\sum_{i=n} y_{i t} \Delta \Theta_{i t}}_{\text {structural transformation }}
$$

where $Y_{t}$ and $y_{i t}$ refer to economy wide and sectoral productivity levels in period $t$, respectively, $\Delta$ denotes changes over time, and $\Theta_{i t}$ is the employment share of sector $i$ in period $t$ (and the index $t-1$ refers to the initial period). There are $n$ sectors in the economy. Hence, the first term on the right-hand side refers to a within sector component of productivity growth, weighted by the employment share of each sector. This kind of growth could occur, for example, due to the accumulation of capital. Likewise, better institutions could increase the efficiency of the different sectors, foster improvements in technology and boost labour productivity. The second term refers to productivity growth due to the structural transformation component which is calculated as the change in sectoral employment shares weighted by the respective sectors productivity level.

According to the dual economy model by Lewis (1954), labour moves from agriculture (traditional, rural) to manufacturing or services (modern, urban). If productivity in manufacturing and services is higher than in agriculture, which is usually the case in developing countries, average labour productivity increases. 7 In our empirical approach we distinguish between two broad sectors $(n=2)$ : agriculture and non-agriculture. Hence, we calculate structural transformation based on labour movements between these two

\footnotetext{
${ }^{6}$ See McMillan et al. (2014) for details.

${ }^{7}$ Note that due to structural transformation average labour productivity could decline as well if workers move from high-productivity to low-productivity sectors.
} 
sectors. 8

As already described before, this fragmentation of sectors is very broad. However, in the case of African economies the simple movement of labour out of agriculture (towards other sectors) plays a huge role and is believed to contribute significantly to the development process.

\subsection{Growth Regression Model}

In terms of the econometric model, we use a simple Solow-type growth framework and add further variables of interest including variables for structural transformation. In such a model, the dependent variable is the growth rate of real GDP per capita, that is, changes over time in the logarithm of labour productivity $\left(\operatorname{grw}\left(Y_{j t}\right)=\ln \left(Y_{j t}\right)-\ln \left(Y_{j t-1}\right)\right)$. The basic model specification reads as follows:

$$
\begin{array}{r}
g r w Y_{j t}=\alpha+\beta \ln \left(Y_{j t-1}\right)+\gamma \ln \left(s_{j t}\right)+\varphi \ln \left(n_{j t}+g+\delta\right) \\
+\eta^{\prime}\left(X_{j t}\right)+\nu^{\prime}\left(T_{j t}\right)+\lambda_{t}+\mu_{j}+\varepsilon_{j t}
\end{array}
$$

where $Y_{j t}$ stands for the real GDP per capita in (an African) country $j$ and period $t$. The main control variables include the savings rate $s$ (proxied by the share of investment in GDP), the population growth rate $n$, improvements in technology $g$, and the depreciation rate of the capital stock $\delta . X_{j t}$ refers to a vector of additional (time-variant and countryspecific) control variables explained below. Moreover, we include period-specific effects $\lambda$, country fixed-effects $\mu$, and an error term $\varepsilon$. We follow large parts of the empirical growth literature and assume that changes in $g$ and $\delta$ are equal to 0.05 and constant over time 9

Our main variables of interest are the measures accounting for structural transformation included in vector $T_{j t}$ in Equation 2, In our preferred specification we consider two measures of structural transformation. On the one hand, we employ the structural transformation component from the decomposition framework. That is, we calculate the

\footnotetext{
${ }^{8}$ Given the continuously (net) decreasing agricultural employment share in all African countries presented in Section 2, labour is constantly moving away from agriculture towards non-agricultural sectors throughout the period 1980-2014.

${ }^{9}$ See, for example, Mankiw et al. (1992) and Hoeffler (2002).
} 
second term on the right-hand-side of Equation 1 for each country and time period. This measure accounts for the dynamics of the transformation process and is therefore named ST-Dynamic. We expect a positive estimate for ST-Dynamic in our regression analysis as we assume that average labour productivity in non-agriculture is higher than in agriculture. On the other hand, we include a variable that addresses the state of structural transformation and is therefore named ST-Static. In other words, a measure accounting for the sectoral employment structure of an economy in each period calculated as non-agricultural employment relative to agricultural employment.

Our expectations regarding the estimate for ST-Static are ambiguous. It is to some extent plausible that it will present with a negative sign. A high level of non-agricultural employment relative to agricultural employment may be associated with lower growth rates as high ratios imply that countries have already seen periods of structural transformation out of agriculture. Hence, there is a lower potential for these economies to benefit from additional structural transformation compared to countries with a lower ratio. In contrast to this interpretation, a positive sign would imply that countries with a high level of employment outside of agriculture are more productive and, therefore, have higher growth rates.

Our regression analysis is to some extend related to the work by Temple and Wößmann (2006). They derive their econometric model from a theoretical framework (a dualistic approach) which explicitly accounts for structural transformation. While their final econometric specification is close to ours, the measurement of the structural transformation variables differs. Moreover, they run a cross-sectional regression while we perform a panel data analysis. A panel approach offers the main advantage of analysing changes in structural transformation and its impact on economic growth over time and across countries 10

In some specifications we consider additional control variables (or drivers) of growth in Africa. We include a human capital index, the inflation rate for macroeconomic distortions, the number of battle deaths for the occurrence and intensity of conflicts, foreign

\footnotetext{
${ }^{10}$ See the descriptive statistics in Appendix $\mathrm{A} 2$ for the (within) variation in our structural transformation variables.
} 
direct investment (FDI) inflows in percent of GDP, and law and order as an indicator for institutional quality ${ }^{11}$ The choice of these particular variables is based on their potential relevance for explaining economic growth in Africa and the availability of the related data.

Apart from lagged GDP per capita, inflation rate and conflicts, we expect a positive impact of all control variables on growth rates. We use five-year averages of all variables to lessen the impact of business cycles. Furthermore, we take logs of all variables but ST-Static, Inflation, and FDI. Due to a lack of complete data before the $1980 \mathrm{~s}$, the period under consideration is limited to 1980 to 2014. That amounts to a maximum of seven periods ${ }^{12}$ The sample consists of 41 African countries, that is, all 48 sub-Saharan African countries apart from Angola, Djibouti, Equatorial Guinea, Liberia, Sao Tome and Principe, Somalia, and South Sudan. For these countries, we either do not have sufficient data or they simply have not existed as a country long enough (South Sudan). Nevertheless, the sample covers a considerable part of the region.

Regarding the methodology, we use a standard OLS fixed-effects panel model. While this method allows for an appropriate identification of the drivers of economic growth across African countries over time, it does not control for the likely endogeneity of most of the independent variables. Also, using the lagged dependent variable in a dynamic panel model can lead to biased estimates (Nickell, 1981). To address both concerns, we also employ a suitable instrumental variable technique, that is, the system Generalized Methods of Moments (GMM) estimator proposed by Blundell and Bond (1998).

\section{Empirical Results}

\subsection{The Relevance of Structural Transformation}

At first, we present calculations based on the decomposition framework of Equation 1 using the employment and value-added data as described in Section 2. This kind of exercise is closely related to McMillan et al. (2014). Yet, there are distinctive differences.

\footnotetext{
${ }^{11}$ See Appendix A1 for exact definitions and data sources of all variables. Descriptive statistics can be found in Appendix A2

${ }^{12}$ The data set is unbalanced as for some countries there is no data available in particular periods.
} 
We address this issue within a broad two sector case motivated with the large relevance of agriculture, while the study by McMillan et al. (2014) draws on much more detailed data covering ten sectors. However, the latter approach comes at a price. Such disaggregated data are only available for a limited amount of African countries. The authors consider only nine out of 48 sub-Saharan African countries ${ }^{13}$ Consequently, the study is rather selective and cannot reflect the region's whole picture. Instead, our aim is to provide figures based on a more representative sample.

Given the two sector approach we calculate all relevant variables for agriculture and non-agriculture (as an aggregate of manufacturing and services). In other words, we differentiate between agriculture and the "rest of the formal economy". Sectoral labour productivity $\left(y_{i t}\right)$ is measured by value-added per employee while the employment share $\left(\Theta_{i t}\right)$ is sectoral employment divided by total employment. All calculations are based on annual data. We present the decomposition results in the form of growth rates in Table 1 where the numbers refer to the mean of the considered measure in the indicated context. We begin with the means of the full sample stated in the first row. In the period 1980-2014 the average economy-wide productivity growth is 0.94 percent which is consistent with a productivity change of roughly 41 US dollars per employee across Africa. The decomposition exercise shows that structural transformation contributes almost 90 percent (82 percentage points) while within sector improvements contribute roughly 10 percent (12 percentage points). This finding suggests that the largest part of productivity change is due to movement or reallocation of labour. Taking into account the four facts in Section 2, we conclude that labour moves out of agriculture towards other sectors where it is employed more efficiently. Hence, on average, structural transformation appears to be growth-inducing in Africa.

Next, we consider particular time periods. Between 1980 and 1999 the average productivity growth rate amounts to about 0.22 percent. This is significantly lower than the full sample average. Yet, it is still positive although one could have expected negative values in this time period considering the negative GDP per capita growth rates illustrated

\footnotetext{
${ }^{13}$ The sample covers the following nine African countries: South Africa, Mauritius, Nigeria, Senegal, Kenya, Ghana, Zambia, Ethiopia, and Malawi.
} 
Table 1: Decomposition of Productivity Growth Rates

\begin{tabular}{lccc}
\hline & $\begin{array}{c}\text { Productivity } \\
\text { growth }\end{array}$ & $\begin{array}{c}\text { Within } \\
\text { component }\end{array}$ & $\begin{array}{c}\text { Structural } \\
\text { transformation }\end{array}$ \\
\hline Full sample & $0.94 \%$ & $0.12 \%$ & $0.82 \%$ \\
\hline Time periods: & & & \\
$\mathbf{1 9 8 0}$ to 1999 & $0.22 \%$ & $-0.61 \%$ & $0.83 \%$ \\
$\mathbf{2 0 0 0}$ to 2014 & $1.81 \%$ & $1 \%$ & $0.81 \%$ \\
\hline Country samples: & & & \\
MRV (9 countries) & $1.15 \%$ & $0.51 \%$ & $0.64 \%$ \\
Not MRV (32 countries) & $0.89 \%$ & $0.01 \%$ & $0.88 \%$ \\
\hline
\end{tabular}

Notes: All calculations are based on annual data. The values are growth rates in percent. The full sample covers 41 countries and 35 years (1980-2014). "MRV" refers to the country sample included in the analysis of McMillan et al. (2014) and covers nine countries. "Not MRV" refers to the 32 countries which we additionally include in our analysis.

in Figure 1 ${ }^{14}$ An additional outcome is that all of the positive productivity growth is due to structural transformation. Within sector changes are even negative indicating that on average the entire economic progress in this period stems from constant labour movements towards non-agricultural sectors. In contrast to that, the most recent period paints a completely different picture. Structural transformation and within component contribute almost equally to positive productivity growth between 2000 and 2014 across Africa. Moreover, the average economy wide growth rate amounts to roughly 1.81 percent which is by far higher than in the previous period. Finally, the results strikingly indicate that (on average) structural transformation has continuously been a growth-enhancing factor across Africa in the last decades

It should be noted that a country-specific analysis shows a heterogeneous picture among African economies. Details can be found in Appendix A3. There is a considerable variation between countries. In terms of economy-wide productivity change, some countries (like the Central African Republic or the Democratic Republic of Congo) have negative values while others (such as Botswana and Mauritius) have large positive values. Botswana and Mauritius are interesting examples as most of the productivity increase is

\footnotetext{
${ }^{14}$ The fact that we use annual per employee data to calculate productivity change is likely to be the reason why there is a difference compared to the negative per capita growth rates shown in Figure 1 .
} 
due to within sector improvements (Botswana about 80 percent and Mauritius about 95 percent). Only a minor part stems from structural transformation which is at odds with the Africa-wide average as shown in Table 1.

Turning to the last two rows of Table 1, we provide results for the full period (1980 to 2014) based on different country samples. A comparison between the findings based on the country sample used in the study by McMillan et al. (2014) - MRV - and the numbers of the first row (full sample) reveals considerable differences. The average economy-wide growth rate for the nine MRV countries is larger (1.15 percent) and the contribution of both components appears to be much more equally distributed. However, both results highlight the relevance of structural transformation. Finally, considering the last row related to the 32 African economies additionally included in our analysis, we have evidence that structural transformation is even more important for the majority of African countries since productivity growth was almost completely driven by the reallocation of labour between sectors.

Nonetheless, our approach carries potential deficits in accurately reflecting the decomposition of productivity change. First, a simple two sector differentiation (which is due to the availability of disaggregated data) may bias the calculations in favour of nonagricultural sectors. It is likely that there are also labour productivity gaps between manufacturing and services. Hence, labour movements from agriculture to manufacturing may have different effects with respect to structural transformation than reallocation from agriculture to services. Yet, in both non-agricultural sectors labour productivity is expected to be significantly higher than in agriculture (Restuccia et al., 2008). Due to this stylised fact, we consider it justified to employ a two-sector approach for Africa. In addition, a comparison with McMillan et al. (2014) shows that we obtain similar results when considering their sample of countries and analysis period from 2000 to 2005.

Second, the employed decomposition framework only considers the reallocation of the production factor labour. The reallocation of capital between sectors and its effective use is not emphasised in this framework. Questions such as "How much do capital movements contribute to structural transformation?" or "Is it a simultaneous reallocation of 
labour and capital or a separate reallocation of the two factors that make structural transformation effective?" cannot be answered with this type of framework. Overall, in the context of labour movements we do observe a remarkably high relevance of structural transformation for productivity growth.

\subsection{Drivers of Economic Growth in Africa}

We proceed with the investigation of the causes of economic growth in Africa, including the relevance of structural transformation, as outlined in the previous section based on Equation 2. We begin with the OLS fixed-effects regressions and the classic Solow growth variables which include lagged GDP per Capita, Investment and Population Growth (Column 1 in Table 2). We find evidence for convergence effects (negative coefficient of lagged GDP per Capita) and an expected positive correlation of investment with growth rates. The estimated coefficients are broadly in line with previous estimates 15 Yet population growth rates are positive and even significantly associated with economic growth. While this outcome is a bit puzzling, the variable renders to be insignificant when we control for endogeneity later. Considering the heterogeneity of the sample, the overall fit of the model is reasonable with a (within) R-squared of 0.46 .

Next, we add our two main variables of interest which measure structural transformation in African economies (Columns 2 to 4). First, we add ST-Dynamic measuring the dynamics of the structural transformation process. The estimated coefficient of roughly 0.06 is positive and highly significant (at the one percent level). That is, structural transformation in form of labour movements from less productive agriculture towards more productive manufacturing or services is highly correlated with economic growth. The variable ST-Static measures the state of structural transformation. It also enters significantly positive, although the coefficient is a little smaller compared with ST-Dynamic. This indicates that African countries with a higher ratio of non-agricultural relative to agricultural employment obtain higher growth rates. In Column 4 we include both variables simultaneously. Obviously, this does not change the findings - the size of the coef-

\footnotetext{
${ }^{15}$ Hoeffler $(2002)$, for example, obtains similar figures.
} 
ficients is similar while the significance remains and even increases regarding ST-Static. It is worth noting that while we include the structural transformation variables, the estimates related to the (Solow) control variables are also not considerably affected in terms of statistical significance and size. We consider the model in Column 4 as our preferred specification which will be the basis for the further analysis addressing endogeneity issues and robustness checks.

Table 2: Fixed-Effects Regressions

\begin{tabular}{lcccc}
\hline & $(1)$ & $(2)$ & $(3)$ & $(4)$ \\
\hline GDP per Capita $(t-1)$ & $-0.175^{* * *}$ & $-0.220^{* * *}$ & $-0.180^{* * *}$ & $-0.231^{* * *}$ \\
& $(-4.949)$ & $(-8.455)$ & $(-4.971)$ & $(-8.928)$ \\
Investment & $0.114^{* * *}$ & $0.108^{* * *}$ & $0.115^{* * *}$ & $0.109^{* * *}$ \\
& $(4.360)$ & $(4.661)$ & $(4.380)$ & $(4.776)$ \\
Population Growth & $0.0624^{*}$ & $0.0541^{* *}$ & $0.0657^{* *}$ & $0.0593^{* *}$ \\
& $(1.999)$ & $(2.125)$ & $(2.113)$ & $(2.441)$ \\
ST-Dynamic & & $0.0593^{* * *}$ & & $0.0627^{* * *}$ \\
& & $(3.390)$ & & $(3.396)$ \\
ST-Static & & & $0.0085^{*}$ & $0.0142^{* * *}$ \\
& & & $(1.828)$ & $(3.075)$ \\
\hline Observations & 220 & 220 & 220 & 220 \\
Countries & 41 & 41 & 41 & 41 \\
R-squared (within) & 0.46 & 0.52 & 0.47 & 0.53 \\
\hline
\end{tabular}

Notes: The dependent variable is always the growth rate of real GDP per capita. All variables are in logs apart from ST-Static. All regressions include period-specific and country-specific dummies. t-values obtained from robust standard errors in parentheses. ${ }^{*}, * *, * * *$ indicate $10,5,1$ percent significance level, respectively.

In the next step, we address endogeneity concerns by using system GMM estimations. The outcome is presented in Table 3. The results of our preferred specification (Column 1) are broadly in line with those obtained from the fixed-effects estimation. Most notably, the two indicators for structural transformation are still positive and statistically significant. The coefficient related to ST-Dynamic is at 0.192 which is even higher than the one in the fixed-effects model. Hence, it is precisely the process of labour movements out of agriculture towards other sectors (where the factor is employed more efficiently) that appears to significantly drive economy-wide productivity growth. The degree of structural transformation (measured by ST-Static) also plays a role, but, the coefficient is considerably smaller. Overall, this evidence suggests that structural transformation has a causal 
effect on economic growth in Africa.

In the system GMM estimations, we treat all variables as endogenous. Moreover, we use the collapse option in Stata and only one instrument per endogenous variable to keep the number of instruments as small as possible. All standard test statistics, such as the Hansen test for overidentifying restrictions, indicate that the instruments used are appropriate. Also, we do have first order autocorrelation but not second order autocorrelation.

Based on the estimated coefficients in Column 1, we can calculate the economic significance of structural transformation for economic growth. An increase in ST-Dynamic by one standard deviation (0.439) leads to an increase in the growth rate of real GDP per capita of 8.4 percentage points over the five-year period. This underlines the fact that structural transformation is not only of statistical significance but of considerable economic relevance for boosting economic growth rates in the long-run.

Before proceeding with further robustness checks, we consider human capital accumulation in Column 2 as an additional Solow control variable. It is well documented in the literature that human capital accumulation is likely to be a key driver of economic growth. In addition to one of the main contributions by Mankiw et al. (1992) and more recent studies (such as Manuelli and Seshadri, 2014), there are also Africa-specific analyses (see Hoeffler, 2002) that address the role of human capital. We employ the human capital index (in logs) from the Penn World Tables 9.0 given by Human Capital. ${ }^{16}$ Unexpectedly, the estimate for Human Capital turns out to be negative but insignificant while the other coefficients remain mostly in line with the preferred model in Column 1, except ST-Static which is now also insignificant. Thus, the result suggests that human capital accumulation is not correlated with growth.

Although there could be many reasons why Human Capital is insignificant ${ }^{17}$, we must

\footnotetext{
${ }^{16}$ This index is based on educational data such as the average years of schooling from Barro and Lee (2013). See Feenstra et al. (2015) for details on the construction of the index.

${ }^{17}$ For instance, there may be substantial time lags in the impact of educational attainment levels on growth. In addition, the considerable heterogeneity in the quality of education in Africa may also play a role. In fact, there has been a strong expansion in schooling in Africa in recent decades, but the quality of education has not improved as much (Glewwe et al., 2014). Hence, the index might not measure human capital levels appropriately which explains the insignificant outcome.
} 
take note that including Human Capital is also associated with a considerable decrease in the sample size. Due to lack of data, the number of countries drops down from 41 to 35. As the aim of this paper is to include as many African countries as possible and human capital appears to not be relevant for economic growth, we exclude Human Capital in the following robustness checks.

Next, we perform further robustness checks by selecting different sample variations. In Column 3 we exclude South Africa from our sample. As South Africa appears to be an outlier in Africa in terms of economic development and structural transformation, it is likely that it biases the overall results. Yet, it turns out that most of the results remain similar if South Africa is excluded, although the degree of structural transformation (STStatic) becomes insignificant. This is understandable as South Africa is the economy with the highest levels of ST-Static, that is, non-agricultural employment relative to agricultural employment. The outcome suggests that for the other 40 economies with lower levels of ST-Static structural transformation in terms of employment in the nonagricultural sectors is not relevant for growth. Once more, this finding highlights that it is the dynamic process of structural transformation that turns out to be a key driver of growth. Additionally, we run similar regressions where we always reduce the sample by one (other) country (not reported for brevity). Most of the results in these regressions remain comparable to Column 1 in terms of both size and significance of all coefficients. At the end, there are four regressions with reduced samples where we also observe an insignificant coefficient for ST-Static as in the case without South Africa. These regressions exclude either Mozambique, Namibia, Sierra Leone or Sudan. We take notice that the relevance of the state of structural transformation should be considered with caution.

The associated literature examines also other factors potentially determining economic growth. To address this issue, we add relevant variables in the context of African economies to our preferred specification. The regression output is displayed in Column 4. We consider an indicator for conflicts (Conflicts) measured by the number of battle deaths (low estimate, see Gleditsch et al. (2002) for details), a proxy for macroeconomic stability (Inflation) measured by the inflation rate, a variable accounting for foreign direct 
investment $(F D I)$ measured as net FDI inflows in percent of GDP, and an indicator for trade (Trade) measured by the sum of total exports and imports in percent of GDP. To reduce the skewness in the data, we take the logarithm of all variables.

Including the additional variables reduces the number of observations to 198 due to some missing values in the data. Nevertheless, our test statistics still suggest that the estimation is appropriate. Yet, there are considerable changes in the estimates compared to the baseline specification in Column 1. Lagged GDP per Capita and ST-Static become insignificant while Investment and ST-Dynamic remain significant. This outcome implies that we do not have evidence for convergence in African countries. While surprising at first view, it is in line with previous findings (e.g. McCoskey, 2002).

With respect to structural transformation we observe that it is only the dynamic variable ST-Dynamic that still plays a role (as it is significant on the ten percent level), while ST-Static becomes insignificant. Moreover, the coefficients of Conflicts and Inflation are negative as expected - the presence of major conflicts and a high inflation rate are detrimental for growth. However, the estimates are insignificant. Foreign investment seems to be a further determinant of economic growth as the estimate is positive and significant on the ten percent level. International trade appears to be not relevant in this cross-country regression.

Finally, we add a variable for the quality of institutions ${ }^{18}$ This indicator is given by Law and Order, where higher values are associated with better institutions. It is positive and significantly associated with growth. Note, however, that it only measures certain aspects of institutional quality and due to data availability constraints our sample is reduced to only 29 countries. Hence, the coefficients of all other variables are no more comparable to the previous estimations. Most notably, our indicators for structural transformation are both insignificant in the reduced sample. It is likely that institutions are correlated with structural transformation as they may be a precondition for this process. This is a potential reason for the insignificance of ST-Dynamic and ST-Static.

\footnotetext{
${ }^{18}$ The relevance of institutions and, in particular, institutional quality for economic growth is highlighted in many studies. Prominent examples are, among others, Acemoglu et al. (2001) and Acemoglu and Robinson (2010).
} 
Table 3: Endogeneity Issues and Robustness Checks

\begin{tabular}{|c|c|c|c|c|c|}
\hline & $\begin{array}{c}(1) \\
\text { Preferred } \\
\text { Specification }\end{array}$ & $\begin{array}{c}(2) \\
\text { Human } \\
\text { Capital }\end{array}$ & $\begin{array}{c}(3) \\
\text { Without } \\
\text { ZAF }\end{array}$ & $\begin{array}{l}\text { (4) } \\
\text { Additional } \\
\text { Controls }\end{array}$ & $\begin{array}{c}\quad(5) \\
\text { Additional: } \\
\text { Institutions }\end{array}$ \\
\hline GDP per Capita $(t-1)$ & $\begin{array}{c}-0.146^{* * *} \\
(-2.743)\end{array}$ & $\begin{array}{l}-0.0850^{*} \\
(-1.926)\end{array}$ & $\begin{array}{c}-0.145^{* *} \\
(-2.331)\end{array}$ & $\begin{array}{l}-0.0734 \\
(-1.269)\end{array}$ & $\begin{array}{c}-0.0711^{* *} \\
(-2.004)\end{array}$ \\
\hline Investment & $\begin{array}{c}0.212^{* * *} \\
(3.341)\end{array}$ & $\begin{array}{c}0.334^{* * *} \\
(5.347)\end{array}$ & $\begin{array}{c}0.209^{* * *} \\
(3.161)\end{array}$ & $\begin{array}{c}0.181^{* *} \\
(2.111)\end{array}$ & $\begin{array}{c}0.218^{* * *} \\
(5.251)\end{array}$ \\
\hline Population Growth & $\begin{array}{l}0.0848 \\
(1.007)\end{array}$ & $\begin{array}{c}0.0015 \\
(0.0070)\end{array}$ & $\begin{array}{l}0.0908 \\
(1.029)\end{array}$ & $\begin{array}{l}0.0655 \\
(0.949)\end{array}$ & $\begin{array}{l}-0.206^{*} \\
(-1.796)\end{array}$ \\
\hline ST-Dynamic & $\begin{array}{c}0.192^{* * *} \\
(3.275)\end{array}$ & $\begin{array}{c}0.113^{* * *} \\
(3.460)\end{array}$ & $\begin{array}{c}0.192^{* * *} \\
(3.131)\end{array}$ & $\begin{array}{l}0.136^{*} \\
(1.738)\end{array}$ & $\begin{array}{l}0.0191 \\
(0.511)\end{array}$ \\
\hline ST-Static & $\begin{array}{c}0.0174^{* *} \\
(2.168)\end{array}$ & $\begin{array}{l}0.0142 \\
(1.547)\end{array}$ & $\begin{array}{l}0.0212 \\
(1.318)\end{array}$ & $\begin{array}{l}0.0098 \\
(1.483)\end{array}$ & $\begin{array}{l}0.0084 \\
(0.834)\end{array}$ \\
\hline Human Capital & & $\begin{array}{l}-0.159 \\
(-0.967)\end{array}$ & & & \\
\hline Conflicts & & & & $\begin{array}{l}-0.0027 \\
(-0.111)\end{array}$ & $\begin{array}{l}-0.0257^{*} \\
(-1.865)\end{array}$ \\
\hline Inflation & & & & $\begin{array}{l}-0.0004 \\
(-0.0082)\end{array}$ & $\begin{array}{l}-0.0219 \\
(-0.834)\end{array}$ \\
\hline FDI & & & & $\begin{array}{c}0.0453^{*} \\
(1.905)\end{array}$ & $\begin{array}{c}0.0645^{*} \\
(1.814)\end{array}$ \\
\hline Trade & & & & $\begin{array}{l}-0.173 \\
(-1.023)\end{array}$ & $\begin{array}{l}-0.145 \\
(-1.156)\end{array}$ \\
\hline Law and Order & & & & & $\begin{array}{c}0.153^{* *} \\
(2.486)\end{array}$ \\
\hline Observations & 220 & 189 & 214 & 198 & 137 \\
\hline Countries & 41 & 35 & 40 & 41 & 29 \\
\hline AB 1 (p-value) & 0.07 & 0.02 & 0.07 & 0.09 & 0.04 \\
\hline AB 2 (p-value) & 0.46 & 0.55 & 0.45 & 0.62 & 0.71 \\
\hline Instruments & 5 & 6 & 5 & 9 & 10 \\
\hline Hansen test (p-value) & 0.57 & 0.37 & 0.57 & 0.63 & 0.72 \\
\hline
\end{tabular}

Notes: The dependent variable is always the growth rate of real GDP per capita. All variables are in logs apart from ST-Static. All regressions include period-specific dummies. Estimations are based on the two-step system-GMM estimator with robust standard errors; corresponding $\mathrm{z}$-values are reported in parentheses. ${ }^{*}, * *, * * *$ indicate $10,5,1$ percent significance level, respectively. AB 1 (2) refers to the Arellano-Bond-test that first-order (second-order) autocorrelation in residuals is 0 .

Nevertheless, it is more likely that it is the reduced country sample that drives the observed finding as the estimates obtained from system GMM with such a small sample size are potentially biased.

In conclusion, we observe that structural transformation plays a significant role for economic growth across Africa. In this context, it is more the dynamic change rather 
than the state of structural transformation that matters.

\section{Discussion and Conclusion}

Recently, structural transformation has gained renewed attention in the development and growth debate. In the last few decades growth economists cited improvements in technology, institutions, economic integration, and other fundamentals as determining factors for long-term growth. However, it has become increasingly clear that economies stuck in low-productivity sectors (mostly agriculture) experience little to no growth despite good fundamentals. Against this backdrop, the study at hand analysed the drivers of economic growth in Africa with special attention on structural transformation. Using two distinct analytical frameworks, we show that structural transformation, defined as the shift of labour from agricultural to non-agricultural sectors, has a significant impact on African growth rates.

In the growth decomposition framework, we can confirm and extend results of two previous studies (McMillan et al., 2014, de Vries et al., 2015) on the importance of structural transformation for long-run growth in Africa. While aggregate growth was mostly driven by structural transformation in the 1980s and 1990s, our decomposition analysis further reveals that in recent years (2000-2014) within-sector growth and structural transformation contributed almost equally to aggregate growth in Africa. Thus, our evidence suggests that structural transformation is a stable long-run factor for economic growth in Africa. In addition, our regression analysis provides robust evidence for the significant impact of structural transformation on growth in Africa, as a result of dynamic labour shifts from agriculture to other (high-productivity) economic sectors.

However, our results come with certain limitations due to the quality and availability of African statistics. It is well known that there is considerable room for improvements in the accuracy of national accounts, as large parts of African economies are not reported adequately. For example, the statistical office of Nigeria rebased its GDP figures from 1990 to 2010 recently (Nigerian National Bureau of Statistics, 2014). Apart from a remarkable increase in Nigeria's total GDP for the year 2013 by no less than 89 percent, the share of 
manufacturing in GDP increased from below two percent to nearly seven percent due to the rebased GDP. This could imply that structural transformation in Nigeria (as well as in other African countries) is underreported. In addition, much of the economic activity in Africa, especially in agriculture, is informal, underreported and thus also hard to quantify. It could very well be that employment and productivity in any sector is much higher or lower than official data says it is.

Moreover, the relevance of structural transformation based on a two-sector approach distinguishing between agriculture and non-agriculture (all other sectors) must be taken with caution. For instance, we cannot trace whether former agricultural workers are absorbed by the manufacturing or services sector. It may be the case that labour movements from agriculture to manufacturing have different effects with respect to structural transformation than reallocation from agriculture to services. As manufacturing plays a minor role for most African countries, it is safe to assume that most workers move from agriculture into services. However, while there are likely considerable labour productivity differences between manufacturing and services, labour productivity in both non-agricultural sectors is commonly assumed to be significantly higher than in agriculture. Under these circumstances, we consider a two-sector approach appropriate.

To conclude, our empirical results should not be read as if agriculture is obsolete and every African economy's structure needs to shift towards non-agricultural sectors in order to grow. Instead, our analysis reveals two policy implications for African countries that rely heavily on agriculture, and have low rates of structural transformation and economic growth. First, these countries could focus on improving agricultural labour productivity to increase overall economic growth, disregarding structural transformation towards other economic sectors. Second, they could facilitate structural transformation, that is, encourage labour movements from agriculture to high-productivity non-agricultural sectors to increase overall economic growth

In order to assess which option is feasible for any given country, future research needs to focus on understanding the root causes of Africa's high economic dependency and low labour productivity in agriculture and derive policy recommendations needed to tackle 
them. For instance, Restuccia et al. (2008) who analyse the role of agriculture for aggregate productivity growth find that across countries (i) low labour productivity in agriculture may be due to barriers to advanced intermediate products, and (ii) high employment shares in agriculture may be due to labour market barriers in non-agricultural sectors. Although the analysis is not Africa-specific the results likely apply to many African countries and could give some impulse for trade and labour market policy reforms. Either way, given that many African countries have high shares of employment in agriculture (more than 60 percent in 20 countries in 2014, (FAO, 2015)), there is still large untapped potential for future productivity growth and structural transformation in Africa. 


\section{References}

Acemoglu, D., Johnson, S., and Robinson, J. A. (2001). The Colonial Origins of Comparative Development: An Empirical Investigation. American Economic Review, 91(5):1369-1401.

Acemoglu, D. and Robinson, J. (2010). The Role of Institutions in Growth and Development. Review of Economics and Institutions, 1(2).

Barro, R. J. and Lee, J. W. (2013). A New Data Set of Educational Attainment in the World, 1950-2010. Journal of Development Economics, 104:184-198.

Blundell, R. and Bond, S. (1998). Initial Conditions and Moment Restrictions in Dynamic Panel Data Models. Journal of Econometrics, 87(1):115-143.

de Vries, G., Timmer, M., and de Vries, K. (2015). Structural Transformation in Africa: Static Gains, Dynamic Losses. Journal of Development Studies, 51(6):674-688.

FAO (2015). FAO Statistics. assessed July 10, 2015, http://faostat.fao.org/.

Feenstra, R. C., Inklaar, R., and Timmer, M. P. (2015). The Next Generation of the Penn World Table. American Economic Review, 105(10):3150-3182.

Gleditsch, N. P., Wallensteen, P., Eriksson, M., Sollenberg, M., and Strand, H. (2002). Armed Conflict 1946-2001: A New Dataset. Journal of Peace Research, 39(5):615-637.

Glewwe, P., Maïga, E., and Zheng, H. (2014). The Contribution of Education to Economic Growth: A Review of the Evidence, with Special Attention and an Application to SubSaharan Africa. World Development, 59:379-393.

Herrendorf, B., Rogerson, R., and Ákos Valentinyi (2014). Growth and Structural Transformation. In Aghion, P. and Durlauf, S. N., editors, Handbook of Economic Growth, volume 2 of Handbook of Economic Growth, chapter 6, pages 855-941. Elsevier.

Hoeffler, A. E. (2002). The Augmented Solow Model and the African Growth Debate. Oxford Bulletin of Economics and Statistics, 64(2):135-158.

IMF (2012). Regional Economic Outlook: Sub-Saharan Africa - Maintaining Growth in an Uncertain World. Technical report, International Monetary Fund, Washington.

Kuznets, S. (1966). Modern Economic Growth: Rate, Structure, and Spread, volume 2. Yale University Press, New Haven.

Lewis, W. A. (1954). Economic Development with Unlimited Supplies of Labour. The Manchester School, 22(2):139-191. 
Mankiw, N. G., Romer, D., and Weil, D. N. (1992). A Contribution to the Empirics of Economic Growth. Quarterly Journal of Economics, 107(2):407-437.

Manuelli, R. E. and Seshadri, A. (2014). Human Capital and the Wealth of Nations. American Economic Review, 104(9):2736-2762.

McCoskey, S. K. (2002). Convergence in Sub-Saharan Africa: A Nonstationary Panel Data Approach. Applied Economics, 34(7):819-829.

McMillan, M. and Harttgen, K. (2014). What is Driving the 'African Growth Miracle'? Working Paper 20077, National Bureau of Economic Research.

McMillan, M., Rodrik, D., and Verduzco-Gallo, Í. (2014). Globalization, Structural Change, and Productivity Growth, with an Update on Africa. World Development, $63: 11-32$.

Nickell, S. (1981). Biases in Dynamic Models with Fixed Effects. Econometrica, 49(6):1417-1426.

OECD, AfDB, UNDP, and UNECA (2013). African Economic Outlook 2013: Structural Transformation and Natural Resources. Annual report, Organisation of Economic Cooperation and Development, Paris.

Restuccia, D., Yang, D. T., and Zhu, X. (2008). Agriculture and Aggregate Productivity: A Quantitative Cross-Country Analysis. Journal of Monetary Economics, 55(2):234250 .

Rodrik, D. (2014). The Past, Present, and Future of Economic Growth. In Allen, F., Behrman, J. R., Birdsall, N., Fardoust, S., Rodrik, D., Steer, A., and Subramanian, A., editors, Towards a Better Global Economy: Policy Implications for Citizens Worldwide in the 21st Century, pages 70-137. Oxford University Press, Oxford.

Rodrik, D. (2016). Premature Deindustrialization. Journal of Economic Growth, 21(1):133.

Temple, J. and Wößmann, L. (2006). Dualism and Cross-Country Growth Regressions. Journal of Economic Growth, 11(3):187-228.

World Bank (2016). World Development Indicators. assessed June 11, 2016, http: //data.worldbank.org. 


\section{Appendix}

\section{A1 Definition of Variables and Data Sources}

\begin{tabular}{|c|c|c|}
\hline Variable & Definition & Data Source \\
\hline GDP per Capita & GDP per capita, constant $\$$ US 2005 & World Bank $(2016)$ \\
\hline Investment & Gross capital formation, $\%$ of GDP & World Bank $(\overline{\overline{2016}})$ \\
\hline Population Growth & Population growth rate in $\%$ & World Bank $(2016)$ \\
\hline ST-Dynamic & $\begin{array}{l}\text { Dynamics of structural transformation calculated } \\
\text { from the sum of changes in sectoral employment } \\
\text { shares weighted by sectoral productivity (based } \\
\text { on employment and GDP, constant } \$ \text { US 2005) }\end{array}$ & $\begin{array}{l}\text { FAO }(2015) \text { and World } \\
\text { Bank }(2016)\end{array}$ \\
\hline ST-Static & $\begin{array}{l}\text { State of structural transformation defined as non- } \\
\text { agricultural employment relative to agricultural } \\
\text { employment }\end{array}$ & FAO 2015 \\
\hline Human Capital & Human capital index & PWT 9.0 \\
\hline Conflicts & Number of battle deaths, low estimate & Gleditsch et al. $(2002)$ \\
\hline Inflation & GDP deflator, annual change in $\%$ & World Bank (2016) \\
\hline FDI & Net FDI inflows, $\%$ of GDP & World Bank \\
\hline Trade & $\begin{array}{l}\text { Total exports and imports of goods and services, } \\
\% \text { of GDP }\end{array}$ & World Bank (2016) \\
\hline Law and Order & $\begin{array}{l}\text { Law and order, } 0-6 \text {, higher figures stand for better } \\
\text { institutions or better law and order, respectively }\end{array}$ & PRS Group (2014) \\
\hline
\end{tabular}

Notes: The PWT (Penn World Tables) 9.0 are explained in Feenstra et al. (2015) , assessed Oct., 2016. Gleditsch et al. (2002) is related to data from the Uppsala conflict data program (UCDP), assessed June, 2016.

\section{A2 Descriptive Statistics}

\begin{tabular}{|c|c|c|c|c|c|}
\hline Variable & Obs. & Mean & Std. dev. & Minimum & Maximum \\
\hline GDP per Capita Growth Rate & 220 & 0.042 & $\begin{array}{c}0.132 \\
(0.101)\end{array}$ & -0.422 & 0.380 \\
\hline $\ln ($ GDP per Capita) & 220 & 6.535 & $\begin{array}{c}1.041 \\
(0.185)\end{array}$ & 4.973 & 9.584 \\
\hline $\ln ($ Investment $)$ & 220 & 2.917 & $\begin{array}{c}0.460 \\
(0.331)\end{array}$ & 1.376 & 4.180 \\
\hline $\ln$ (Population Growth Rate) & 220 & 2.885 & $\begin{array}{c}0.323 \\
(0.230)\end{array}$ & 1.358 & 3.494 \\
\hline $\ln ($ ST-Dynamic) & 220 & 4.019 & $\begin{array}{c}1.290 \\
(0.439)\end{array}$ & 0.993 & 7.904 \\
\hline ST-Static & 220 & 1.137 & $\begin{array}{c}2.150 \\
(0.754)\end{array}$ & 0.083 & 15.76 \\
\hline
\end{tabular}

Notes: All descriptive statistics are calculated on the basis of the sample from the baseline estimation. The numbers in parentheses refer to the within standard deviation of the respective variable. 


\section{A3 Decomposition of Productivity Change by Country}

\begin{tabular}{|c|c|c|c|}
\hline & $\begin{array}{l}\text { Productivity } \\
\text { change }(\Delta Y)\end{array}$ & $\begin{array}{c}\text { Within } \\
\text { component }\end{array}$ & $\begin{array}{c}\text { Structural } \\
\text { transformation }\end{array}$ \\
\hline Benin & 3.204 & -7.854 & 11.06 \\
\hline Botswana & 427.8 & 330.9 & 96.87 \\
\hline Burkina Faso & 15.92 & 15.48 & .4448 \\
\hline Burundi & -2.306 & -4.726 & 2.421 \\
\hline Cabo Verde & 158.6 & 141 & 17.53 \\
\hline Cameroon & .1737 & -35.79 & 35.96 \\
\hline Central African & -13.82 & -20.73 & 6.904 \\
\hline Chad & 28.51 & 14.51 & 13.99 \\
\hline Comoros & -9.366 & -19.32 & 9.951 \\
\hline Congo, Dem. Rep. & -22.44 & -28.43 & 5.99 \\
\hline Congo, Rep. & 29.94 & -25.42 & 55.36 \\
\hline Cote d'Ivoire & -35.02 & -61.04 & 26.02 \\
\hline Ethiopia & 7.373 & 3.979 & 3.394 \\
\hline Gabon & -12.19 & -173.2 & 161 \\
\hline Gambia, The & -6.786 & -14.99 & 8.205 \\
\hline Ghana & 20.55 & 18.5 & 2.055 \\
\hline Guinea & 1.185 & -9.395 & 10.58 \\
\hline Guinea-Bissau & 5.868 & -1.823 & 7.691 \\
\hline Kenya & 2.77 & -9.42 & 12.19 \\
\hline Lesotho & 36.2 & 32.26 & 3.931 \\
\hline Madagascar & -11.49 & -18.14 & 6.65 \\
\hline Malawi & 4.162 & -1.087 & 5.249 \\
\hline Mali & 19.49 & -.171 & 19.66 \\
\hline Mauritania & 3.771 & -10.08 & 13.85 \\
\hline Mauritius & 325.5 & 305.2 & 20.25 \\
\hline Mozambique & 22.69 & 18.6 & 4.082 \\
\hline Namibia & 49.93 & -64.13 & 114.1 \\
\hline Niger & -9.428 & -18.36 & 8.934 \\
\hline Nigeria & 34.66 & 32.83 & 1.826 \\
\hline Rwanda & 8.518 & 3.447 & 5.072 \\
\hline Senegal & 3.927 & -13.33 & 17.25 \\
\hline Seychelles & 325.9 & 12.08 & 313.9 \\
\hline Sierra Leone & 8.388 & 5.66 & 2.728 \\
\hline South Africa & 10.75 & -24.58 & 35.34 \\
\hline Sudan & 37.95 & 23.29 & 14.66 \\
\hline Swaziland & 86.37 & 42.86 & 43.52 \\
\hline Tanzania & 18.74 & 8.992 & 9.744 \\
\hline Togo & -9.752 & -15.3 & 5.544 \\
\hline Uganda & 15.75 & 7.835 & 7.919 \\
\hline Zambia & 9.362 & -9.371 & 18.73 \\
\hline Zimbabwe & -2.421 & -18.84 & 16.42 \\
\hline
\end{tabular}

Note: All calculations are based on annual data between 1980 and 2014 applying Equation 1 . 


\section{Hohenheim Discussion Papers in Business, Economics and Social Sciences}

The Faculty of Business, Economics and Social Sciences continues since 2015 the established "FZID Discussion Paper Series" of the "Centre for Research on Innovation and Services (FZID)" under the name "Hohenheim Discussion Papers in Business, Economics and Social Sciences".

\section{Institutes}

$510 \quad$ Institute of Financial Management

520 Institute of Economics

530 Institute of Health Care \& Public Management

540 Institute of Communication Science

550 Institute of Law and Social Sciences

560 Institute of Economic and Business Education

570 Institute of Marketing \& Management

580 Institute of Interorganisational Management \& Performance

\section{Research Areas (since 2017)}

INEPA "Inequality and Economic Policy Analysis"

TKID "Transformation der Kommunikation - Integration und Desintegration"

NegoTrans "Negotiation Research - Transformation, Technology, Media and Costs"

INEF "Innovation, Entrepreneurship and Finance"

Download Hohenheim Discussion Papers in Business, Economics and Social Sciences from our homepage: https://wiso.uni-hohenheim.de/papers

\section{No. Author \\ 01-2015 Thomas Beissinger, Philipp Baudy}

02-2015 Fabian Wahl

03-2015 Tommaso Proietti, Martyna Marczak, Gianluigi Mazzi

04-2015 Thomas Beissinger, Nathalie Chusseau, Joël Hellier

05-2015 Matthias Mueller, Kristina Bogner, Tobias Buchmann, Muhamed Kudic

06-2015 Martyna Marczak, Thomas Beissinger

07-2015 Peng Nie, Galit Nimrod, Alfonso Sousa-Poza
Title Inst

THE IMPACT OF TEMPORARY AGENCY WORK 520 ON TRADE UNION WAGE SETTING:

A Theoretical Analysis

PARTICIPATIVE POLITICAL INSTITUTIONS AND CITY DEVELOPMENT 800-1800

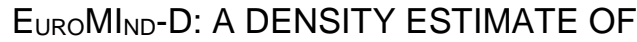
MONTHLY GROSS DOMESTIC PRODUCT FOR THE EURO AREA

OFFSHORING AND LABOUR MARKET REFORMS: MODELLING THE GERMAN EXPERIENCE

SIMULATING KNOWLEDGE DIFFUSION IN FOUR 520 STRUCTURALLY DISTINCT NETWORKS - AN AGENT-BASED SIMULATION MODEL

BIDIRECTIONAL RELATIONSHIP BETWEEN 520 INVESTOR SENTIMENT AND EXCESS RETURNS: NEW EVIDENCE FROM THE WAVELET PERSPECTIVE

INTERNET USE AND SUBJECTIVE WELL-BEING IN CHINA 
No. Author

Title

Inst

08-2015 Fabian Wahl

09-2015 Peng Nie, Alfonso Sousa-Poza

10-2015 Kristina Bogner

11-2015 Bogang Jun, Tai-Yoo Kim

12-2015 Volker Grossmann Aderonke Osikominu Marius Osterfeld

13-2015 Martyna Marczak Tommaso Proietti Stefano Grassi

14-2015 Carolina Castagnetti Luisa Rosti Marina Töpfer

15-2015 Alexander Opitz

01-2016 Michael Ahlheim, Jan Neidhardt

02-2016 Bogang Jun, Alexander Gerybadze, Tai-Yoo Kim

03-2016 Peng Nie, Alfonso Sousa-Poza

04-2016 Peter Spahn

05-2016 Vincent Dekker, Kristina Strohmaier, Nicole Bosch

06-2016 Philipp Baudy, Dario Cords
THE LONG SHADOW OF HISTORY

ROMAN LEGACY AND ECONOMIC DEVELOPMENT

520

- EVIDENCE FROM THE GERMAN LIMES

COMMUTE TIME AND SUBJECTIVE WELL-BEING IN URBAN CHINA

530

THE EFFECT OF PROJECT FUNDING ON INNOVATIVE PERFORMANCE AN AGENT-BASED SIMULATION MODEL

520

A NEO-SCHUMPETERIAN PERSPECTIVE ON THE ANALYTICAL MACROECONOMIC FRAMEWORK: THE EXPANDED REPRODUCTION SYSTEM

ARE SOCIOCULTURAL FACTORS IMPORTANT FOR STUDYING A SCIENCE UNIVERSITY MAJOR?

520

A DATA-CLEANING AUGMENTED KALMAN FILTER FOR ROBUST ESTIMATION OF STATE SPACE MODELS

520

THE REVERSAL OF THE GENDER PAY GAP AMONG PUBLIC-CONTEST SELECTED YOUNG EMPLOYEES

520

DEMOCRATIC PROSPECTS IN IMPERIAL RUSSIA: THE REVOLUTION OF 1905 AND THE POLITICAL STOCK MARKET

NON-TRADING BEHAVIOUR IN CHOICE EXPERIMENTS

THE LEGACY OF FRIEDRICH LIST: THE EXPANSIVE REPRODUCTION SYSTEM AND THE KOREAN HISTORY OF INDUSTRIALIZATION

FOOD INSECURITY AMONG OLDER EUROPEANS: 530 EVIDENCE FROM THE SURVEY OF HEALTH, AGEING, AND RETIREMENT IN EUROPE

POPULATION GROWTH, SAVING, INTEREST RATES AND STAGNATION. DISCUSSING THE EGGERTSSONMEHROTRA-MODEL

A DATA-DRIVEN PROCEDURE TO DETERMINE THE BUNCHING WINDOW - AN APPLICATION TO THE NETHERLANDS

DEREGULATION OF TEMPORARY AGENCY EMPLOYMENT IN A UNIONIZED ECONOMY: DOES THIS REALLY LEAD TO A SUBSTITUTION OF REGULAR EMPLOYMENT? 
No. Author

07-2016 Robin Jessen Davud Rostam-Afschar, Sebastian Schmitz

08-2016 Peng Nie, Alfonso Sousa-Poza, Jianhong Xue

09-2016 Bogang Jun, Seung Kyu-Yi, Tobias Buchmann, Matthias Müller

10-2016 Vladan Ivanovic, Vadim Kufenko, Boris Begovic Nenad Stanisic, Vincent Geloso

11-2016 David E. Bloom Michael Kuhn Klaus Prettner

12-2016 Franz X. Hof Klaus Prettner

13-2016 Jung-In Yeon Andreas Pyka Tai-Yoo Kim

14-2016

Benjamin Fuchs

15-2016 Seung-Kyu Yi Bogang Jun

16-2016 Gregor Pfeifer Fabian Wahl Martyna Marczak

17-2016 Malte Klein Andreas Sauer

18-2016 Klaus Prettner

19-2016 Klaus Prettner Andreas Schaefer

20-2016 Vadim Kufenko Klaus Prettner
HOW IMPORTANT IS PRECAUTIONARY LABOR SUPPLY?

520

FUEL FOR LIFE: DOMESTIC COOKING FUELS

530 AND WOMEN'S HEALTH IN RURAL CHINA

THE CO-EVOLUTION OF INNOVATION NETWORKS: COLLABORATION BETWEEN WEST AND EAST GERMANY FROM 1972 TO 2014

CONTINUITY UNDER A DIFFERENT NAME. 520 THE OUTCOME OF PRIVATISATION IN SERBIA

THE CONTRIBUTION OF FEMALE HEALTH TO ECONOMIC DEVELOPMENT

THE QUEST FOR STATUS AND R\&D-BASED GROWTH

STRUCTURAL SHIFT AND INCREASING VARIETY IN KOREA, 1960-2010: EMPIRICAL EVIDENCE OF THE ECONOMIC DEVELOPMENT MODEL BY THE CREATION OF NEW SECTORS

THE EFFECT OF TEENAGE EMPLOYMENT ON CHARACTER SKILLS, EXPECTATIONS AND OCCUPATIONAL CHOICE STRATEGIES

HAS THE GERMAN REUNIFICATION

520 STRENGTHENED GERMANY'S NATIONAL INNOVATION SYSTEM? TRIPLE HELIX DYNAMICS OF GERMANY'S INNOVATION SYSTEM

ILLUMINATING THE WORLD CUP EFFECT: NIGHT LIGHTS EVIDENCE FROM SOUTH AFRICA

520

CELEBRATING 30 YEARS OF INNOVATION

570 SYSTEM RESEARCH: WHAT YOU NEED TO KNOW ABOUT INNOVATION SYSTEMS

THE IMPLICATIONS OF AUTOMATION FOR 520 ECONOMIC GROWTH AND THE LABOR SHARE

HIGHER EDUCATION AND THE FALL AND RISE OF INEQUALITY

YOU CAN'T ALWAYS GET WHAT YOU WANT? ESTIMATOR CHOICE AND THE SPEED OF CONVERGENCE 
No.

Author

Title

Inst

01-2017 Annarita Baldanzi

Alberto Bucci

Klaus Prettner

02-2017 Julius Tennert

Marie Lambert

Hans-Peter Burghof

03-2017 Michael Ahlheim

Oliver Frör

Nguyen Minh Duc

Antonia Rehl

Ute Siepmann

Pham Van Dinh

04-2017 Bohdan Kukharskyy Sebastian Seiffert

05-2017 Ana Abeliansky Klaus Prettner

06-2017 Vincent Geloso

Vadim Kufenko

07-2017 Emanuel Gasteiger

Klaus Prettner

08-2017 Klaus Prettner

Holger Strulik

09-2017 David E. Bloom

Simiao Chen

Michael Kuhn

Mark E. McGovern

Les Oxley

Klaus Prettner

10-2017 Sebastian Till Braun Nadja Dwenger

11-2017 Vadim Kufenko Klaus Prettner Vincent Geloso

12-2017 Frank M. Fossen

Ray Rees

Davud Rostam-Afschar

Viktor Steiner

13-2017 Steffen Otterbach

Michael Rogan

14-2017 Carolina Castagnetti

Luisa Rosti

Marina Töpfer
CHILDRENS HEALTH, HUMAN CAPITAL

INEPA

ACCUMULATION, AND R\&D-BASED ECONOMIC GROWTH

MORAL HAZARD IN VC-FINANCE: MORE EXPENSIVE THAN YOU THOUGHT

INEF

LABOUR AS A UTILITY MEASURE

520 RECONSIDERED

GUN VIOLENCE IN THE U.S.: CORRELATES AND

520

CAUSES

AUTOMATION AND DEMOGRAPHIC CHANGE

520

INEQUALITY AND GUARD LABOR, OR

PROHIBITION AND GUARD LABOR?

INEPA

ON THE POSSIBILITY OF AUTOMATION-INDUCED

520

STAGNATION

THE LOST RACE AGAINST THE MACHINE:

INEPA

AUTOMATION, EDUCATION, AND INEQUALITY IN AN R\&D-BASED GROWTH MODEL

THE ECONOMIC BURDEN OF CHRONIC

520

DISEASES: ESTIMATES AND PROJECTIONS FOR CHINA, JAPAN, AND SOUTH KOREA

THE LOCAL ENVIRONMENT SHAPES REFUGEE INTEGRATION: EVIDENCE FROM POST-WAR GERMANY

DIVERGENCE, CONVERGENCE, AND THE HISTORY-AUGMENTED SOLOW MODEL

HOW DO ENTREPRENEURIAL PORTFOLIOS RESPOND TO INCOME TAXATION?

INEPA

INEPA

520

SPATIAL DIFFERENCES IN STUNTING AND

INEPA HOUSEHOLD AGRICULTURAL PRODUCTION IN SOUTH AFRICA: (RE-) EXAMINING THE LINKS USING NATIONAL PANEL SURVEY DATA

THE CONVERGENCE OF THE GENDER PAY GAP - AN ALTERNATIVE ESTIMATION APPROACH 
No.

Author

Title

Inst

15-2017 Andreas Hecht

16-2017 Mareike Schoop

D. Marc Kilgour (Editors)

17-2017 Mareike Schoop

D. Marc Kilgour (Editors)

18-2017 Sibylle Lehmann-Hasemeyer Fabian Wahl

19-2017 Stephanie Glaser

20-2017 Dario Cords

21-2017 Micha Kaiser Jan M. Bauer

22-2017 Thilo R. Huning Fabian Wahl

23-2017 Matthias Busse Ceren Erdogan Henning Mühlen
ON THE DETERMINANTS OF SPECULATION - A 510 CASE FOR EXTENDED DISCLOSURES IN CORPORATE RISK MANAGEMENT

PROCEEDINGS OF THE $17^{\text {TH }}$ INTERNATIONAL NegoTrans CONFERENCE ON GROUP DECISION AND NEGOTIATION

DOCTORAL CONSORTIUM OF THE $17^{\text {TH }}$

NegoTrans INTERNATIONAL CONFERENCE ON GROUP DECISION AND NEGOTIATION

SAVING BANKS AND THE INDUSTRIAL

520 REVOLUTION IN PRUSSIA SUPPORTING REGIONAL DEVELOPMENT WITH PUBLIC FINANCIAL INSTITUTIONS

A REVIEW OF SPATIAL ECONOMETRIC MODELS FOR COUNT DATA

ENDOGENOUS TECHNOLOGY, MATCHING, AND

INEPA LABOUR UNIONS: DOES LOW-SKILLED IMMIGRATION AFFECT THE TECHNOLOGICAL ALIGNMENT OF THE HOST COUNTRY?

PRESCHOOL CHILD CARE AND CHILD WELLBEING IN GERMANY: DOES THE MIGRANT EXPERIENCE DIFFER?

LORD OF THE LEMONS: ORIGIN AND DYNAMICS OF STATE CAPACITY

STRUCTURAL TRANSFORMATION AND ITS RELEVANCE FOR ECONOMIC GROWTH IN SUBSHARAN AFRICA 
(published 2009-2014)

\section{Competence Centers}

IK Innovation and Knowledge

ICT Information Systems and Communication Systems

CRFM Corporate Finance and Risk Management

$\mathrm{HCM} \quad$ Health Care Management

CM Communication Management

MM Marketing Management

ECO Economics

Download FZID Discussion Papers from our homepage: https://wiso.uni-hohenheim.de/archiv_fzid_papers

\begin{tabular}{|c|c|c|c|}
\hline Nr. & Autor & Titel & CC \\
\hline 01-2009 & Julian P. Christ & $\begin{array}{l}\text { NEW ECONOMIC GEOGRAPHY RELOADED: } \\
\text { Localized Knowledge Spillovers and the Geography of Innovation }\end{array}$ & IK \\
\hline 02-2009 & André P. Slowak & $\begin{array}{l}\text { MARKET FIELD STRUCTURE \& DYNAMICS IN INDUSTRIAL } \\
\text { AUTOMATION }\end{array}$ & IK \\
\hline 03-2009 & $\begin{array}{l}\text { Pier Paolo Saviotti, } \\
\text { Andreas Pyka }\end{array}$ & $\begin{array}{l}\text { GENERALIZED BARRIERS TO ENTRY AND ECONOMIC } \\
\text { DEVELOPMENT }\end{array}$ & IK \\
\hline 04-2009 & $\begin{array}{l}\text { Uwe Focht, Andreas } \\
\text { Richter and Jörg } \\
\text { Schiller }\end{array}$ & INTERMEDIATION AND MATCHING IN INSURANCE MARKETS & $\mathrm{HCM}$ \\
\hline 05-2009 & $\begin{array}{l}\text { Julian P. Christ, } \\
\text { André P. Slowak }\end{array}$ & $\begin{array}{l}\text { WHY BLU-RAY VS. HD-DVD IS NOT VHS VS. BETAMAX: } \\
\text { THE CO-EVOLUTION OF STANDARD-SETTING CONSORTIA }\end{array}$ & $\mathrm{IK}$ \\
\hline 06-2009 & $\begin{array}{l}\text { Gabriel Felbermayr, } \\
\text { Mario Larch and } \\
\text { Wolfgang Lechthaler }\end{array}$ & UNEMPLOYMENT IN AN INTERDEPENDENT WORLD & $\mathrm{ECO}$ \\
\hline 07-2009 & Steffen Otterbach & $\begin{array}{l}\text { MISMATCHES BETWEEN ACTUAL AND PREFERRED WORK } \\
\text { TIME: Empirical Evidence of Hours Constraints in } 21 \text { Countries }\end{array}$ & $\mathrm{HCM}$ \\
\hline 08-2009 & Sven Wydra & $\begin{array}{l}\text { PRODUCTION AND EMPLOYMENT IMPACTS OF NEW } \\
\text { TECHNOLOGIES - ANALYSIS FOR BIOTECHNOLOGY }\end{array}$ & IK \\
\hline 09-2009 & $\begin{array}{l}\text { Ralf Richter, } \\
\text { Jochen Streb }\end{array}$ & $\begin{array}{l}\text { CATCHING-UP AND FALLING BEHIND } \\
\text { KNOWLEDGE SPILLOVER FROM AMERICAN } \\
\text { TO GERMAN MACHINE TOOL MAKERS }\end{array}$ & IK \\
\hline
\end{tabular}


Nr.

Autor

Titel

CC

KYOTO AND THE CARBON CONTENT OF TRADE

ECO

Gabriel Felbermayr

11-2010 David E. Bloom,

ECONOMIC CONSEQUENCES OF LOW FERTILITY IN EUROPE

$\mathrm{HCM}$

Alfonso Sousa-Poza

12-2010 Michael Ahlheim, Oliver Frör

DRINKING AND PROTECTING - A MARKET APPROACH TO THE PRESERVATION OF CORK OAK LANDSCAPES

ECO

LABOUR AS A UTILITY MEASURE IN CONTINGENT VALUATION STUDIES - HOW GOOD IS IT REALLY?

ECO

Oliver Frör,

Antonia Heinke,

Nguyen Minh Duc,

and Pham Van Dinh

14-2010 Julian P. Christ

THE GEOGRAPHY AND CO-LOCATION OF EUROPEAN

IK

TECHNOLOGY-SPECIFIC CO-INVENTORSHIP NETWORKS

15-2010 Harald Degner

WINDOWS OF TECHNOLOGICAL OPPORTUNITY

DO TECHNOLOGICAL BOOMS INFLUENCE THE RELATIONSHIP BETWEEN FIRM SIZE AND INNOVATIVENESS?

16-2010 Tobias A. Jopp

THE WELFARE STATE EVOLVES:

GERMAN KNAPPSCHAFTEN, 1854-1923

$\mathrm{HCM}$

17-2010 Stefan Kirn (Ed.)

PROCESS OF CHANGE IN ORGANISATIONS THROUGH

ICT

eHEALTH

18-2010 Jörg Schiller

ÖKONOMISCHE ASPEKTE DER ENTLOHNUNG

$\mathrm{HCM}$

UND REGULIERUNG UNABHÄNGIGER

VERSICHERUNGSVERMITTLER

19-2010 Frauke Lammers,

CONTRACT DESIGN AND INSURANCE FRAUD: AN

$\mathrm{HCM}$

Jörg Schiller

EXPERIMENTAL INVESTIGATION

REAL WAGES AND THE BUSINESS CYCLE IN GERMANY

ECO

Thomas Beissinger

21-2010 Harald Degner,

Jochen Streb

FOREIGN PATENTING IN GERMANY, 1877-1932

IK

DOES DOWNWARD NOMINAL WAGE RIGIDITY

DAMPEN WAGE INCREASES?

ECO

Thomas Beissinger

23-2010 Mark Spoerer,

GUNS AND BUTTER - BUT NO MARGARINE: THE IMPACT OF Jochen Streb

NAZI ECONOMIC POLICIES ON GERMAN FOOD

ECO CONSUMPTION, 1933-38 
Nr.

Autor

Titel

24-2011 Dhammika Dharmapala, Nadine Riedel

25-2011 Michael Schuele, Stefan Kirn

26-2011 Marcus Müller, Guillaume Stern, Ansger Jacob and Stefan Kirn

27-2011 Monnet Benoit, Patrick Gbakoua and Alfonso Sousa-Poza

28-2011 Nadine Riedel, Hannah SchildbergHörisch

29-2011 Nicole Waidlein

30-2011 Dominik Hartmann, Atilio Arata

31-2011 Peter Spahn

32-2011 Fabian Wahl

33-2011 Giorgio Triulzi, Ramon Scholz and Andreas Pyka

34-2011 Claus D. MüllerHengstenberg, Stefan Kirn

35-2011 Andreas Pyka

36-2011 David Bell, Steffen Otterbach and Alfonso Sousa-Poza

37-2011 Lukas Scheffknecht, Felix Geiger

38-2011 Yin Krogmann, Ulrich Schwalbe
EARNINGS SHOCKS AND TAX-MOTIVATED INCOME-SHIFTING: EVIDENCE FROM EUROPEAN MULTINATIONALS

ECO

ICT

QUALITATIVES, RÄUMLICHES SCHLIEßEN ZUR KOLLISIONSERKENNUNG UND KOLLISIONSVERMEIDUNG AUTONOMER BDI-AGENTEN

VERHALTENSMODELLE FÜR SOFTWAREAGENTEN IM ICT PUBLIC GOODS GAME

ECO

ENGEL CURVES, SPATIAL VARIATION IN PRICES AND

DEMAND FOR COMMODITIES IN CÔTE D'IVOIRE

ASYMMETRIC OBLIGATIONS

ECO

CAUSES OF PERSISTENT PRODUCTIVITY DIFFERENCES IN THE WEST GERMAN STATES IN THE PERIOD FROM 1950 TO 1990

MEASURING SOCIAL CAPITAL AND INNOVATION IN POOR AGRICULTURAL COMMUNITIES. THE CASE OF CHÁPARRA PERU

DIE WÄHRUNGSKRISENUNION

DIE EURO-VERSCHULDUNG DER NATIONALSTAATEN ALS SCHWACHSTELLE DER EWU

ECO

DIE ENTWICKLUNG DES LEBENSSTANDARDS IM DRITTEN REICH - EINE GLÜCKSÖKONOMISCHE PERSPEKTIVE

ECO

R\&D AND KNOWLEDGE DYNAMICS IN UNIVERSITY-INDUSTRY

IK RELATIONSHIPS IN BIOTECH AND PHARMACEUTICALS: AN AGENT-BASED MODEL

ANWENDUNG DES ÖFFENTLICHEN VERGABERECHTS AUF MODERNE IT SOFTWAREENTWICKLUNGSVERFAHREN

ICT

AVOIDING EVOLUTIONARY INEFFICIENCIES

IK IN INNOVATION NETWORKS

WORK HOURS CONSTRAINTS AND HEALTH

$\mathrm{HCM}$

A BEHAVIORAL MACROECONOMIC MODEL WITH

ECO ENDOGENOUS BOOM-BUST CYCLES AND LEVERAGE DYNAMICS

INTER-FIRM R\&D NETWORKS IN THE GLOBAL PHARMACEUTICAL BIOTECHNOLOGY INDUSTRY DURING 1985-1998: A CONCEPTUAL AND EMPIRICAL ANALYSIS 
Nr.

39-2011 Michael Ahlheim, Tobias Börger and Oliver Frör

40-2011 Tobias Börger

41-2011 Ralf Rukwid, Julian P. Christ
RESPONDENT INCENTIVES IN CONTINGENT VALUATION: THE ECO ROLE OF RECIPROCITY

A DIRECT TEST OF SOCIALLY DESIRABLE RESPONDING IN CONTINGENT VALUATION INTERVIEWS

ECO

QUANTITATIVE CLUSTERIDENTIFIKATION AUF EBENE

IK DER DEUTSCHEN STADT- UND LANDKREISE (1999-2008) 
Nr.

Autor

Titel

42-2012 Benjamin Schön,

A TAXONOMY OF INNOVATION NETWORKS

IK

Andreas Pyka

43-2012 Dirk Foremny, Nadine Riedel

BUSINESS TAXES AND THE ELECTORAL CYCLE

ECO

44-2012 Gisela Di Meglio, Andreas Pyka and

VARIETIES OF SERVICE ECONOMIES IN EUROPE

IK

Luis Rubalcaba

45-2012 Ralf Rukwid, Julian P. Christ

INNOVATIONSPOTENTIALE IN BADEN-WÜRTTEMBERG:

IK

PRODUKTIONSCLUSTER IM BEREICH „METALL, ELEKTRO, IKT“ UND REGIONALE VERFÜGBARKEIT AKADEMISCHER FACHKRÄFTE IN DEN MINT-FÄCHERN

46-2012 Julian P. Christ,

INNOVATIONSPOTENTIALE IN BADEN-WÜRTTEMBERG:

IK Ralf Rukwid BRANCHENSPEZIFISCHE FORSCHUNGS- UND ENTWICKLUNGSAKTIVITÄT, REGIONALES PATENTAUFKOMMEN UND BESCHÄFTIGUNGSSTRUKTUR

47-2012 Oliver Sauter

ASSESSING UNCERTAINTY IN EUROPE AND THE

ECO US - IS THERE A COMMON FACTOR?

IK

SEN MEETS SCHUMPETER. INTRODUCING STRUCTUR
DYNAMIC ELEMENTS INTO THE HUMAN CAPABILITY APPROACH

49-2012 Harold ParedesFrigolett, Andreas Pyka

DISTAL EMBEDDING AS A TECHNOLOGY INNOVATION

IK NETWORK FORMATION STRATEGY

CYCLICALITY OF REAL WAGES IN THE USA AND GERMANY: NEW INSIGHTS FROM WAVELET ANALYSIS

ECO

Martyna Marczak Víctor Gómez

DIE DURCHSETZUNG VON SCHNITTSTELLEN

IK IN DER STANDARDSETZUNG:

FALLBEISPIEL LADESYSTEM ELEKTROMOBILITÄT

52-2012 Fabian Wahl

WHY IT MATTERS WHAT PEOPLE THINK - BELIEFS, LEGAL

ECO ORIGINS AND THE DEEP ROOTS OF TRUST

IK

Micha Kaiser

STATISTISCHER ÜBERBLICK DER TÜRKISCHEN MIGRATION IN BADEN-WÜRTTEMBERG UND DEUTSCHLAND

IDENTIFIZIERUNG UND ANALYSE DEUTSCH-TÜRKISCHER INNOVATIONSNETZWERKE. ERSTE ERGEBNISSE DES TGIN-

Andreas Pyka, Seda Aydin, Lena Klauß, Fabian Stahl, Ali PROJEKTES

Santircioglu, Silvia Oberegelsbacher, Sheida Rashidi, Gaye Onan and Suna Erginkoç

55-2012 Michael Ahlheim, Tobias Börger and Oliver Frör DESERT: A CONTINGENT VALUATION STUDY IN RURAL SOUTHWEST CHINA 
Nr. Autor

56-2012 Matthias Strifler Thomas Beissinger

57-2012 Peter Spahn

58-2012 Sibylle H. Lehmann

59-2012 Sibylle H. Lehmann, Philipp Hauber and Alexander Opitz

60-2012 Martyna Marczak, Víctor Gómez

61-2012 Theresa Lohse, Nadine Riedel
FAIRNESS CONSIDERATIONS IN LABOR UNION WAGE SETTING - A THEORETICAL ANALYSIS

INTEGRATION DURCH WÄHRUNGSUNION? DER FALL DER EURO-ZONE

TAKING FIRMS TO THE STOCK MARKET:

IPOS AND THE IMPORTANCE OF LARGE BANKS IN IMPERIAL GERMANY 1896-1913

POLITICAL RIGHTS, TAXATION, AND FIRM VALUATION -

ECO EVIDENCE FROM SAXONY AROUND 1900

SPECTRAN, A SET OF MATLAB PROGRAMS FOR SPECTRAL

ECO ANALYSIS

THE IMPACT OF TRANSFER PRICING REGULATIONS ON PROFIT SHIFTING WITHIN EUROPEAN MULTINATIONALS
ECO

ECO

ECO

ECO 
Nr. Autor

63-2013 David E. Bloom,

AGEING AND PRODUCTIVITY

$\mathrm{HCM}$

Alfonso Sousa-Poza

64-2013 Martyna Marczak,

MONTHLY US BUSINESS CYCLE INDICATORS:

ECO Víctor Gómez

A NEW MULTIVARIATE APPROACH BASED ON A BAND-PASS FILTER

65-2013 Dominik Hartmann,

INNOVATION, ECONOMIC DIVERSIFICATION AND HUMAN

IK

Andreas Pyka

DEVELOPMENT

66-2013 Christof Ernst,

CORPORATE TAXATION AND THE QUALITY OF RESEARCH

ECO

Katharina Richter and AND DEVELOPMENT

Nadine Riede

67-2013 Michael Ahlheim, Oliver Frör, Jiang Tong, Luo Jing and Sonna Pelz

68-2013 Michael Ahlheim, Friedrich Schneider

CONSIDERING HOUSEHOLD SIZE IN CONTINGENT VALUATION STUDIES

69-2013 Fabio Bertoni, Tereza Tykvová

WHICH FORM OF VENTURE CAPITAL IS MOST SUPPORTIVE OF INNOVATION?

EVIDENCE FROM EUROPEAN BIOTECHNOLOGY COMPANIES

70-2013 Tobias Buchmann, Andreas Pyka

THE EVOLUTION OF INNOVATION NETWORKS:

THE CASE OF A GERMAN AUTOMOTIVE NETWORK Pyka, J. A. La Poutré and A. G. de Kok

72-2013 Beatriz Fabiola López Ulloa, Valerie Møller and Alfonso SousaPoza

73-2013 Wencke Gwozdz, Alfonso Sousa-Poza, Lucia A. Reisch, Wolfgang Ahrens, Stefaan De Henauw, Gabriele Eiben, Juan M. Fernández-Alvira, Charalampos Hadjigeorgiou, Eva Kovács, Fabio Lauria, Toomas Veidebaum, Garrath Williams, Karin Bammann

HOW DOES SUBJECTIVE WELL-BEING EVOLVE WITH AGE? 
Nr.

Autor

74-2013 Andreas Haas, Annette Hofmann

75-2013 Yin Krogmann, Nadine Riedel and Ulrich Schwalbe

76-2013 Peter Spahn

77-2013 Sheida Rashidi, Andreas Pyka

78-2013 Benjamin Schön, Andreas Pyka

79-2013 Irene Prostolupow, Andreas Pyka and Barbara Heller-Schuh

80-2013 Eva Schlenker, Kai D. Schmid

81-2013 Michael Ahlheim, Tobias Börger and Oliver Frör

82-2013 Fabian Wahl

83-2013 Peter Spahn

84-2013 Daniel Guffarth, Michael J. Barber
RISIKEN AUS CLOUD-COMPUTING-SERVICES:

$\mathrm{HCM}$ FRAGEN DES RISIKOMANAGEMENTS UND ASPEKTE DER VERSICHERBARKEIT

INTER-FIRM R\&D NETWORKS IN PHARMACEUTICAL

ECO, IK BIOTECHNOLOGY: WHAT DETERMINES FIRM'S CENTRALITY-BASED PARTNERING CAPABILITY?

MACROECONOMIC STABILISATION AND BANK LENDING:

ECO A SIMPLE WORKHORSE MODEL

MIGRATION AND INNOVATION - A SURVEY

IK

THE SUCCESS FACTORS OF TECHNOLOGY-SOURCING THROUGH MERGERS \& ACQUISITIONS - AN INTUITIVE METAANALYSIS

TURKISH-GERMAN INNOVATION NETWORKS IN THE EUROPEAN RESEARCH LANDSCAPE

IK

CAPITAL INCOME SHARES AND INCOME INEQUALITY IN THE EUROPEAN UNION

ECO

THE INFLUENCE OF ETHNICITY AND CULTURE ON THE VALUATION OF ENVIRONMENTAL IMPROVEMENTS - RESULTS FROM A CVM STUDY IN SOUTHWEST CHINA -

DOES MEDIEVAL TRADE STILL MATTER? HISTORICAL TRADE CENTERS, AGGLOMERATION AND CONTEMPORARY ECONOMIC DEVELOPMENT

SUBPRIME AND EURO CRISIS: SHOULD WE BLAME THE ECO ECONOMISTS?

THE EUROPEAN AEROSPACE R\&D COLLABORATION

IK NETWORK

KARTELLBEKÄMPFUNG UND INTERNE KARTELLSTRUKTUREN

IK EIN NETZWERKTHEORETISCHER ANSATZ 
Nr.

Autor

86-2014 Stefan Kirn, Claus D.

INTELLIGENTE (SOFTWARE-)AGENTEN: EINE NEUE

ICT Müller-Hengstenberg HERAUSFORDERUNG FÜR DIE GESELLSCHAFT UND UNSER RECHTSSYSTEM?

87-2014 Peng Nie, Alfonso

MATERNAL EMPLOYMENT AND CHILDHOOD OBESITY IN $\mathrm{HCM}$ Sousa-Poza CHINA: EVIDENCE FROM THE CHINA HEALTH AND NUTRITION SURVEY

88-2014 Steffen Otterbach, Alfonso Sousa-Poza

JOB INSECURITY, EMPLOYABILITY, AND HEALTH:

$\mathrm{HCM}$ AN ANALYSIS FOR GERMANY ACROSS GENERATIONS

89-2014 Carsten Burhop, Sibylle H. LehmannHasemeyer

THE GEOGRAPHY OF STOCK EXCHANGES IN IMPERIAL GERMANY

ECO

90-2014 Martyna Marczak, OUTLIER DETECTION IN STRUCTURAL TIME SERIES Tommaso Proietti MODELS: THE INDICATOR SATURATION APPROACH

Andreas Pyka

92-2014 Bogang Jun, Joongho Lee

THE TRADEOFF BETWEEN FERTILITY AND EDUCATION: EVIDENCE FROM THE KOREAN DEVELOPMENT PATH

NON-FINANCIAL HURDLES FOR HUMAN CAPITAL ACCUMULATION: LANDOWNERSHIP IN KOREA UNDER JAPANESE RULE

94-2014 Michael Ahlheim, Oliver Frör, Gerhard Langenberger and Sonna Pelz

95-2014 Harold ParedesFrigolett, Andreas Pyka, Javier Pereira and Luiz Flávio Autran Monteiro Gomes

CHINESE URBANITES AND THE PRESERVATION OF RARE SPECIES IN REMOTE PARTS OF THE COUNTRY - THE EXAMPLE OF EAGLEWOOD

IK

IK

RANKING THE PERFORMANCE OF NATIONAL INNOVATION SYSTEMS IN THE IBERIAN PENINSULA AND LATIN AMERICA FROM A NEO-SCHUMPETERIAN ECONOMICS PERSPECTIVE

96-2014 Daniel Guffarth, Michael J. Barber 


\section{IMPRINT}

University of Hohenheim

Dean's Office of the Faculty of Business, Economics and Social Sciences Palace Hohenheim $1 \mathrm{~B}$

70593 Stuttgart | Germany

Fon $\quad+49(0) 71145922488$

Fax $\quad+49(0) 71145922785$

E-mail wiso@uni-hohenheim.de

Web www.wiso.uni-hohenheim.de 